\title{
Capital Structure Adjustments: Do Macroeconomic and Business Risks Matter?
}

\author{
Christopher F Baum ${ }^{\mathrm{a}, \mathrm{b}, 1, *}$, Mustafa Caglayan ${ }^{\mathrm{c}}$, Abdul Rashid ${ }^{\mathrm{d}}$ \\ ${ }^{a}$ Department of Economics, Boston College, Chestnut Hill, MA 02467 USA \\ ${ }^{b}$ Department of Macroeconomics, DIW Berlin, 10117 Berlin, Germany \\ ${ }^{c}$ School of Management and Languages, Heriot-Watt University, Edinburgh EH14 4AS, UK \\ ${ }^{d}$ International Institute of Islamic Economics, International Islamic University, 44000, Islamabad, Pakistan
}

\begin{abstract}
We show that risk plays an important role in estimating the adjustment of the firm's capital structure. We find that the adjustment process is asymmetric and depends on the type of risk, its magnitude, the firm's current leverage, and its financial status. We also show that firms with financial surpluses and above-target leverage adjust their leverage more rapidly when firm-specific risk is low and when macroeconomic risk is high. Firms with financial deficits and below-target leverage adjust their capital structure more quickly when both types of risk are low. Our investigation suggests that models without risk factors yield biased results.
\end{abstract}

Keywords: macroeconomic risk; business risk; capital structure rebalancing; speed of adjustment; deviations from target leverage; financial deficits/surpluses JEL classification: C23, D81, E44, G32

\footnotetext{
${ }^{*}$ Corresponding author.

Email addresses: baum@bc.edu (Christopher F Baum), m.caglayan@hw.ac.uk (Mustafa Caglayan), abdulrashid@iiu.edu.pk, Cell: +92 333 2277507, Fax: +92 (51)9258036 (Abdul Rashid)

${ }^{1}$ We would like to thank independent referees and Heather M. Anderson for their constructive suggestions and comments. We would like to thank the participants at the EFMA, Rome 2014, conference for useful comments. The usual disclaimer applies.
} 


\section{Introduction}

Following the seminal paper by Modigliani and Miller (1958), researchers have proposed several analytical models to explain the capital structure of firms. Subsequent empirical studies based on these models have helped us to develop a basic understanding of the factors that affect a firm's capital structure decisions. However, these studies do not fully explain the observed time series and the cross-sectional dynamics of corporate capital structures documented in the literature. A review of the empirical literature provides evidence that there are substantial variations in the speed of adjustment estimates, ranging from half a year to six years. ${ }^{2}$ For instance, Welch (2004) finds that about $60 \%$ of year-to-year fluctuations of firms' leverage are due to firms' issuance activity rather than of firms striving to achieve any specific leverage target. Baker and Wurgler (2002) show that the effects of historical market valuations on leverage are relatively long-lasting, suggesting firms do not actively adjust their capital structure. Yet, several previous studies (e.g., Ozkan (2001), Flannery and Rangan (2006), and Faulkender et al. (2012)), document evidence of a relatively rapid adjustment toward the target. Overall, it seems that corporate leverage is mean reverting at the firm level but the speed at which this happens is not a settled issue.

Is there a resolution to these conflicting results? Some researchers suggest that the seemingly passive attitude of firms toward achieving leverage targets could be due to mismeasurement of the speed of adjustment. It is argued that the standard models of leverage lack power to separate the benefits of achieving targets from other motivations of financing (e.g., see Shyam-Sunder and Myers (1999) and Chang and Dasgupta (2009)). ${ }^{3}$ Others indicate that estimated leverage adjustment speeds in previous studies are biased (e.g., see Flannery and Rangan (2006) and Huang and Ritter (2009)).

\footnotetext{
${ }^{2}$ Table A, Appendix A, displays the speed of adjustment estimates recently reported in the literature.

${ }^{3}$ Researchers have used either the full-adjustment or the partial-adjustment model to examine firms' optimal/target leverage. The full-adjustment model assumes that the adjustment to the specific target leverage will be done in one step. In contrast, the partial adjustment model assumes that the firm will attain the optimal leverage over time.
} 
Another reason why the speed of adjustment estimates differ could be due to variations in the costs and benefits of capital structure adjustments across firms, which may be reflected in variations in the speed at which firms adjust capital structure toward the target (e.g., Byoun (2008), Elsas and Florysiak (2010), Faulkender et al. (2012), and Dang et al. (2012)). These studies indicate that firm-specific factors such as financing gaps, equity market valuations, firm size, profitability, and leverage deviations from the target cause asymmetries in adjustment speed across firms. Other studies, such as Cook and Tang (2010), Drobetz and Wanzenried (2006), and Haas and Peeters (2006), have related the asymmetric speed of adjustment to macroeconomic conditions measured by real GDP.

The models that researchers have examined may have also suffered from omitted factors, which play an important role in the adjustment of leverage. For instance, although it has been shown that risk affects firms' leverage decisions, the extent to which risk affects the speed with which managers adjust firms' capital structure has not been investigated. ${ }^{4}$ In our investigation, we scrutinize the effect of risk on the speed of capital structure adjustments by employing an approach similar to that in Byoun (2008)..$^{5}$ In particular we examine the impact of time-varying firm-specific and macroeconomic risks on the speed of adjustment. We estimate our models applying the System GMM dynamic panel data estimator. This methodology allows us to overcome the biases arising from potential endogeneity, measurement error, and the presence of the lagged dependent variable in the model.

We carry out the empirical investigation for a publicly quoted UK manufacturing firmlevel panel dataset over 1981-2009. We determine the optimal leverage of firms by estimating a dynamic target leverage model, which includes several firm-specific variables along with both macroeconomic and firm-specific (idiosyncratic) risk measures. We then estimate two

\footnotetext{
${ }^{4}$ To our knowledge, using a partial-adjustment model, the only other paper that explores the role of risk on capital adjustment problem is Dang et al. (2012). However, their risk measure is not time-varying, as their model only focuses on the impact of firms' earnings volatility in low vs. high regimes. Likewise, they allow for differing speeds of adjustment for above-threshold and below-threshold financing imbalances, but do not allow the speed of adjustment to vary with the magnitude of risk.

${ }^{5}$ Byoun (2008) investigates the importance of financial imbalances on capital adjustment when the firm is above or below its target level of debt. However, his research is silent about the role of risk.
} 
interrelated models to examine the impact of risk on the capital adjustment problem. We first examine the asymmetric effects of risk on the speed of adjustment when the firm's actual leverage is above or below the target leverage. We find that firms having leverage above the target adjust their capital structure more rapidly when macroeconomic risk is low. In contrast, firms with below-target leverage are more likely to adjust their capital structure quickly toward their targets in times of low firm-specific risk and high macroeconomic risk. This model provides our initial set of observations that risk affects the adjustment speed of firms' leverage.

We then extend this model to examine the role of risk in conjunction with financial imbalances as the firm's leverage lies above or below its target ratio. We find that firms with financial surpluses and above-target leverage are likely to adjust their leverage more quickly toward their target when macroeconomic risk is high but firm-specific risk is low. This observation suggests that a firm that has a financial surplus with leverage exceeding the target quickly readjusts its capital structure in periods of high macroeconomic risk to avoid costs of financial distress along with the likelihood of bankruptcy. In contrast, we observe that firms with financial surpluses and below-target leverage do not strive to achieve their target capital structure, but rather maintain their current state. We argue that in a risky environment, managers of firms with cash use their option to wait rather than inadvertently adjusting the capital structure of the firm. We also find that firms that experience financial deficits with above-target leverage are more likely to issue equity to achieve their target leverage, particularly in times of low macroeconomic risk. ${ }^{6}$ For such firms, given the level of macroeconomic risk, an increase in firm-specific risk accelerates the capital adjustment process. Last we show that firms that have financial deficits with below-target leverage are more likely to adjust their capital structure when both firm-specific and macroeconomic risks are relatively low. An increase in either type of risk retards their process of adjustment.

We examine the robustness of our findings as we consider i) a target leverage estimate

\footnotetext{
${ }^{6}$ As good macroeconomic prospects (low macroeconomic risks) are positively related to the market value of equity, firms generally issue new equity during such periods.
} 
without incorporating the role of risk factors, ii) an alternative definition of leverage measured by total debt/total assets, iii) generating firm-specific risks after controlling for effects of macroeconomic conditions, iv) alternative measures of risk, and v) target leverage based on historical leverage. The results from these alternative approaches confirm our initial observations. Overall, our investigation provides clear evidence that the type of risk (macroeconomic versus firm-specific) and the extent of risk which firms face matter for their capital adjustment process. Our investigation clearly shows that risk exerts asymmetric effects on the firm's capital adjustment process, over and above the firms' financial state or the extent of firms' actual leverage in comparison to the target. These findings are important in understanding managers' actions given the increased risks associated with the recent financial crisis.

The rest of the paper proceeds as follows. Section 2 discusses the hypotheses and our expectations. Section 3 presents information on the dataset and describes the procedures we implement to generate firm-specific and macroeconomic risk measures. Section 4 describes the estimation methods. Section 5 presents the empirical findings and robustness checks, and Section 6 concludes the paper.

\section{Hypotheses on Risk and Leverage Adjustments}

Prior to laying out our hypotheses regarding the effects of macroeconomic and firmspecific risks on the speed of adjustment toward a target leverage ratio as both macroeconomic and firm-specific risks vary over time, it is important to discuss the state of the literature along these lines. A survey of the literature shows that several researchers have rationalized the effects of macroeconomic risk on firm leverage referring to the financial propagation mechanism. This literature suggests that macroeconomic volatility influences the borrowers' collateralizable net worth, and therefore affects their risk premium for external funds. Changes in the risk premium in return influence the ability of the firms to borrow 
funds from potential lenders. ${ }^{7}$

These implications have been taken to data by many researchers. Gertler and Hubbard (1993) show that firms opt for equity rather than debt contracts to shift at least some of the business-cycle risk to their lenders during periods of higher macroeconomic risk. Baum et al. (2009) empirically show that an increase in macroeconomic risk leads to a significant decrease in firms' optimal short-term leverage. Hatzinikolaou et al. (2002) find that inflation uncertainty has a significant negative effect on a firm's debt-equity ratio. More recently, Bhamra et al. (2010) and Chen (2010) using a dynamic capital structure framework show that unpredictable variations in macroeconomic conditions have a significant impact on firms' financing policies. Specifically, Chen (2010) predicts that higher macroeconomic risks lead to a decline in discounted value of expected tax benefits. As the advantages of an outstanding debt stock fall, firms reduce their debt in bad times. Bhamra et al. (2010) argue that firms become more conservative in their use of debt financing during bad states of the economy to have financial flexibility rendering leverage to be pro-cyclical. Caglayan and Rashid (2014) also show that macroeconomic risk is significantly and negatively related to the short-term leverage of pubic and nonpublic UK manufacturing. ${ }^{8}$

Furthermore, there is a deep literature which has argued that firm-specific risk plays an important role in explaining the firm's target leverage. For instance, Fisher (1959) argues that the risk premium which firms pay is significantly associated with their earnings volatility. Likewise, Baxter (1967) documents that the variance of firms' earnings has a negative impact on firms' desirability to rely on debt financing. Brealey and Myers (1981) also argue that firms find financial distress to be costly regardless of the presence or absence of bankruptcy. Firms therefore generally have a tendency to repress their financial distress costs, implying that firms with relatively volatile potential future cash flow streams use less debt in their

\footnotetext{
${ }^{7}$ For theoretical underpinning regarding the effects of macroeconomic shocks on firms' capital structure, see, including others, Bernanke and Gertler (1989), Calomiris and Hubbard (1990), Gertler (1992), Greenwald and Stiglitz (1993), Gertler and Gilchrist (1993), and Kiyotaki and Moore (1997).

8 also see Almeida and Campello (2010), and Öztekin and Flannery (2012) along these lines who examined inflation volatility effects on the firm's capital structure.
} 
capital structure than the others. Using the tax shelter-bankruptcy cost model, Castanias (1983) establishes an inverse relationship between business risk and a firms leverage. He shows that with a given marginal tax rate and marginal default cost function, higher business risk results in a decline in the debt level of firms. In line with bankruptcy cost theory, Bradley et al. (1984) present a single period corporate capital structure model and show the presence of an inverse relation of a firms optimal level of debt with its earnings volatility. ${ }^{9}$

Although the impact of risk on capital structure has been explored by several researchers, risk effects on the adjustment speed toward the firm's target leverage have not hitherto been investigated. We hypothesize that as costs and benefits of rebalancing the capital structure vary with the source of and variations in risk, so does the speed with which firms adjust leverage toward their targets. Hence, we examine the role of risk on the speed of adjustment of leverage while we consider firms' financial status (financial surpluses or financial deficits) and the state of firms' actual leverage (above or below target leverage). In this context, we consider two related empirical models. The first model examines the role of risk on the adjustment speed when we take into account the deviation of leverage from the target, while the second model allows us to investigate the effects of risk on the adjustment speed taking into account both the financial state of the firm and the deviation of leverage from the target.

\section{Model 1: Risk Effects Considering the State of Actual Leverage}

The first model allows us to examine the impact of both macroeconomic and idiosyncratic risks on the speed of adjustment of a firm whose actual leverage falls below or above its target as the risk structure varies. We expect those firms whose actual leverage is above the target to reduce their leverage during periods of low risk. This is because such firms will want to reduce financial distress, which arises due to high levels of debt, by issuing equity or retiring debt. The best time to proceed as such is when both business and macroeconomic risks are at

\footnotetext{
${ }^{9}$ Among others, Taub (1975), Ferri and Jones (1979), Marsh (1982), Titman and Wessels (1988), Wald (1999), and Lemmon et al. (2008) present empirical evidence of a negative and statistically significant relationship between the firm-specific volatility/risk and leverage. Furthermore, several other studies, including Choe et al. (1993), Gertler and Gilchrist (1994), Korajczyk and Levy (2003), Drobetz et al. (2007), Cook and Tang (2010), and Akhtar (Akhtar), arrive at the conclusion that business cycles significantly affects firms' capital structure.
} 
their lowest. In contrast, for firms whose leverage is below their target, we expect to see that the adjustment will be faster during periods of high firm-specific risk, as firms experiencing greater turbulence would prefer to reach their target leverage as quickly as possible. This can be achieved more quickly when macroeconomic risks are low, as it is easier to raise external funds in that environment.

It should be noted that the impact of risk on the adjustment speed should differ as the firm's actual leverage exceeds or falls below its target in comparison to the case when there is no risk. For instance, if the firm's actual leverage exceeds its target, then the presence of risk will delay adjustment, as in a risky environment, the manager may prefer to have a buffer cash stock rather than retiring its debt quickly. Yet, if the actual leverage is below its target, the presence of risk may speed up the process, as the manager would prefer to adjust the firm's capital structure quickly.

Model 2: Risk Effects Considering the State of Actual Leverage and Financial Imbalances

As we examine the importance of risk, we next consider the effect of financial imbalances on capital adjustment when the firm's actual leverage is above or below its target leverage. This leads to four alternative scenarios as the firm experiences a financial surplus or deficit while their leverage is below or above the target.

Scenario 1 is that of a firm which experiences a financial surplus with above-target leverage. In principle, firms that have financial surpluses with above-target leverage can adjust their capital structure by retiring debt. As high levels of debt increase the likelihood of financial distress and firms' risk exposures, firms with above-target debt are more likely to quickly reverse excess deviations from their target leverage ratio. In fact, this reversal should happen more rapidly when the firm is exposed to idiosyncratic or macroeconomic risks, as the costs of distress will then be higher. Consequently, we expect that the speed of adjustment will be highest when both risks are high. This suggests that the adjustment will take place more quickly in a risky environment than in a no-risk environment. As the firm is rich in cash, there is little reason for the manager to carry excessive debt and experience financial distress. 
Scenario 2 is that of a firm which experiences financial deficits with above-target leverage. These firms are expected to reduce their actual leverage in order to offset deviations from their leverage targets and to finance their fixed investments through external resources. The optimal solution to this problem is to issue equity, which can be done most effectively when the macroeconomic and idiosyncratic risks are low. Higher levels of risk will increase the costs associated with issuing equity due to increased asymmetric information problems. Hence, an increase in macroeconomic risk will hinder the adjustment process, as in such circumstances investors reduce their demand for equity due to severe adverse selection problems. However, an increase in firm-specific risk may not have such adverse effects, as the firm will issue new equity through an investment bank that can evaluate its prospects and advise on the issuance of equity. We expect that the speed of adjustment for such firms under risks will be slower than the case in which there is no risk, as raising external funds through equity issuance requires time as investors strive to evaluate the value of the company.

Scenario 3 is that of a firm which experiences a financial surplus with a below-target leverage ratio. Such a firm faces no pressure to raise funds to finance operations by either issuing new debt or repurchasing existing equity. The presence of risk or an increase of either type of risk will induce these firms to adjust their capital structure more slowly, as the associated costs would be higher in periods of high risk. Given that the manager of such a firm under uncertainty would rather have the option to change capital structure in the future, adjustment will be slow.

Scenario 4 is that of a firm which experiences a financial deficit with below-target leverage. In this case, new financing is needed by firms to adjust their capital structure toward the target leverage. Because the firm's actual leverage is below its target, this objective can be achieved by raising funds by issuing debt. Prior empirical research has shown that leverage is negatively affected by risk. Hence, we expect that the speed of adjustment under risk will be highest when both firm-specific and macroeconomic risks are low. However, we also expect that in the presence of risk the speed of adjustment will be higher than the case when there is no risk in the environment. 
In all scenarios, we expect that the speed of adjustment in the presence of risk will differ from the case when there is no risk. Furthermore, we do not expect to see any symmetry over different scenarios and as the extent of risk changes from one level to another. Hence, we expect to find that risk plays an important role in the speed of adjustment of leverage.

\section{Data}

Our investigation uses a firm-level unbalanced annual panel dataset for the United Kingdom. The data are obtained from the WorldScope Global database via DataStream and cover the period 1981-2009. The analysis is carried out for manufacturing firms, each of which contributes at least five years of observations. ${ }^{10,11}$ As routinely implemented in the literature (see, for instance, Baker and Wurgler (2002) and Kayhan and Titman (2007)), we drop firm-year observations if the ratio of book leverage is greater than one. All remaining firm-specific variables are scaled by total assets and are winsorised at the first and ninety-ninth percentile to eliminate the adverse effects of outliers and misreported data. ${ }^{12}$

Following earlier empirical studies, including Baker and Wurgler (2002), Alti (2006), and Kayhan and Titman (2007), we define book equity as total assets minus total liabilities and preferred stock plus deferred taxes and convertible debt. Book debt is equal to total assets minus book equity. Book leverage is then defined as the ratio of book debt to total assets. We investigate book leverage rather than market leverage because market leverage is very sensitive to the market value of equity, which can change substantially due to movements in equity markets even if firms do not alter their actual borrowing. In addition, firms' managers are more concerned about the book value of debt ratio because banks and other financial institutions utilize the book value of debt in ascertaining the creditworthiness of a firm. Similarly, credit-rating agencies, such as Standard \& Poor's, Moody's, and A.M. Best, also

\footnotetext{
${ }^{10}$ We mitigate sample selection and survivorship biases by allowing for both entry and exit in the sample.

${ }^{11}$ We restrict our attention to those firms which contribute at least five years of observations to generate meaningful measures of risk at the firm level and to properly instrument the endogenous variables in estimating our model.

${ }^{12}$ The data screening we implement here is commonly applied in the literature ( e.g., see, including others, Brav (2009), Baum et al. (2009), Kayhan and Titman (2007), and Baker and Wurgler (2002)).
} 
consider the book value of debt in determining a firm's credit rating. ${ }^{13}$

Firm size is defined as the logarithm of net sales. Asset tangibility is equal to the ratio of net plant, property, and equipment to the book value of total assets. Profitability is the ratio of earnings before interest, taxes, and depreciation to the book value of total assets. The two-year stock return is defined as the percentage change between share prices at time $t-2$ and share prices at time $t$. The market-to-book value ratio is equal to book debt plus market equity divided by the book value of total assets. Market equity is common shares outstanding multiplied by the market price of each share. The non-debt tax shield is defined as total depreciation expense divided by the book value of total assets.

To investigate the impact of risk on firms' financial decisions, we consider two types of risk: firm-specific risk, derived from firms' sales to total assets ratio, and macroeconomic risk, which is computed using real gross domestic product (GDP). ${ }^{14}$ Details on all variables are given in Table B of Appendix B.

\subsection{Measuring Firm-Specific Risk}

We estimate an autoregressive model of order one $(A R(1))$ for firms' annual sales normalized by the book value of total assets to generate firm-specific risk based on the residuals of the model as suggested in Caglayan and Rashid (2014) and Bo (2002). We estimate the following model for each firm:

$$
\text { Sales }_{i, t}=\mu_{i}+\varphi \text { Sales }_{i, t-1}+\zeta_{i, t}
$$

where Sales $_{i, t}$ is the ratio of sales to book value of total assets for firm $i$ at time $t, \mu_{i}$ captures the fixed effects, $\varphi$ is the autoregressive parameter, and $\zeta_{i, t}$ is the error term with zero mean and finite variance. We obtain the residuals from the above $A R(1)$ process for each firm and compute the cumulative variance of the obtained residuals. Specifically, the risk proxy for 2000 is constructed by calculating the variance of the residuals obtained from the

\footnotetext{
${ }^{13}$ See Shyam-Sunder and Myers (1999) and Frank and Goyal (2003) along these lines.

${ }^{14}$ Seasonally adjusted quarterly data spanning 1975Q1-2009Q4 on UK real GDP are taken from the Office for National Statistics (ONS) database (Pn: A2: ABMI: Gross Domestic Product: chained volume measure).
} 
AR(1) model of sales that uses data for 2000 and 1999. Similarly, the risk measure for 2001 is constructed calculating the variance of the residuals obtained from the same model using the data for 2001, 2000 and 1999. The process is repeated similarly. The downside of this approach is the loss of one observation per firm. The square root of the estimated cumulative variance, denoted by $R_{i, t}^{\text {firm }}$, is used as a proxy for firm-specific risk in the empirical investigation. Given that each firm contributes at least five years of observations, the measure above uses a minimum of four observations to generate the risk measure.

\subsection{Measuring Macroeconomic Risk}

To generate a proxy for macroeconomic risk, we estimate an $A R C H$ model on quarterly real GDP over 1975-2009. We include an $A R(1)$ term in the mean equation of our $A R C H(1)$ specification and estimate the following model:

$$
\begin{aligned}
\Delta G D P_{t} & =\omega+\eta \Delta G D P_{t-1}+\epsilon_{t} \\
\sigma_{t}^{2} & =\alpha+\beta \epsilon_{t-1}^{2}
\end{aligned}
$$

where $\omega$ is a constant term and $\eta$ is the autoregressive parameter. The estimated conditional variance, $\hat{\sigma}_{t}^{2}$, is the one-period-ahead forecast variance based on prior information. $\alpha$ is the constant and $\epsilon_{t} \mid \Delta G D P_{t-1} \sim N\left(0, \sigma_{t-1}^{2}\right)$ is the innovation in real GDP.

The model is estimated using the maximum likelihood method. The conditional variance, $\hat{\sigma}_{t}^{2}$, is then annualized averaging over four quarters to match the frequency of the firm level data. The generated series is denoted by $R_{t}^{\text {macro }}$ and used as a proxy for macroeconomic risk. The $A R C H$ coefficient $(\beta=0.781)$ is less than one and is statistically significant at the $1 \%$ level.

\subsection{Summary Statistics}

Table 1 provides the summary statistics of the firm-specific variables for the full sample as well as three subperiods. Book leverage, with a mean of 0.574 for the full sample, has increased over time suggesting that firms, on average, were less levered and were not as actively involved in altering their leverage in the 1980s in comparison to the later years of the sample period. 
The average fixed capital expenditures (investment) to book value of total assets ratio is 0.059 for the entire sample period. In contrast to leverage, it appears that the investment rate has declined over the sample period. Similar patterns can be observed for firms' profitability. On average, firms were more profitable during the first ten years of the sample period. Reductions in average profitability during the last nine years of the sample could be one of the reasons why firms' fixed capital investment, on average, has declined.

The average two-year stock return is 0.098 for the full sample period, yet it is negative with a value of -0.134 and a high standard deviation during the last nine years of the sample period. Firms' share prices rose in the 1990s, as average stock returns are positive and higher than in the other two subperiods. The mean values of tangibility and firm size, measured by the $\log$ of total net sales, are 0.287 and 11.141, respectively, for the whole sample period. Inspecting the behavior of both variables, we see that while the means of both series monotonically declined, their volatility increased over time. Finally, we observe that the average non-debt tax shield for the full sample is 0.052 , yet it exhibits an increasing trend over the years.

Overall, the summary statistics across the three subperiods show that firms are relatively more leveraged, earn lower returns on their assets, have lower fixed investment expenditures, and have a declining trend in their equity value in the later years of the sample, particularly over the 2001-09 period.

Table 2 provides the summary statistics of our risk measures for the full sample and subsamples. The table shows that firm-specific risk has consistently increased over time. Specifically, the average firm-specific risk during the 1980s and 1990s was considerably less than that of the 2001-09 period. We also observe that firm-specific risk was more volatile during the last nine years of the sample, as its standard deviation is higher in these years compared to the 1980s and the 1990s. This implies that firms experienced greater risks associated with their operations in the latter years of the sample. Similar to the case of firm-specific risk, macroeconomic risk also appears to be on the rise throughout the period of investigation. Further, the estimated standard deviations provide evidence that the macroeconomic 
environment is more volatile over the 2001-2009 period as compared to earlier years.

In summary, both macroeconomic risk and firm-specific risk have increased markedly and became more volatile over the recent years: quite understandably, as the financial crisis towards the end of the sample period took its toll on businesses and the economy. ${ }^{15}$

\section{Empirical Implementation}

We present two models to examine the effects of both firm-specific and macroeconomic risk measures on the adjustment of capital structure. The first model allows us to investigate the role of risk on the speed of adjustment of the capital structure when firms' actual leverage is below or above the target. The second model, an extension of the first model, allows us to examine the effects of risk as we consider the state of firms' financial balances and the state of firms' actual leverage with respect to the target.

\subsection{The Target Adjustment Model}

We compute the firm-specific target debt ratio, $L_{i, t}^{T}$, using the following specification:

$$
L_{i, t}^{T}=\beta_{1} X_{i, t-1}+\beta_{2} R_{i, t-1}^{\text {firm }}+\beta_{3} R_{t-1}^{\text {macro }}+v_{i}+\varepsilon_{i, t}
$$

where $X_{i, t}$ is a vector of firm-specific variables that includes the lagged value of leverage, the market-to-book value ratio, firm profitability, asset tangibility, capital investment expenditures-to-total assets ratio, two-year stock returns, non-debt tax shields and the log of firm sales as a proxy for firm size. The model contains time-varying firm-specific and macroeconomic volatility measures as denoted by $R_{i, t}^{\text {firm }}$ and $R_{t}^{\text {macro }}$, respectively. ${ }^{16}$ The term $v_{i}$ captures time-invariant unobservable firm-specific fixed effects. The term $\epsilon_{i, t}$ is the idiosyncratic error term. ${ }^{17}$

\footnotetext{
${ }^{15}$ The empirical correlation of the risk measures of 0.002 implies that each measure covers a different aspect of risk associated with the business and macroeconomic environment that firms face in their operations.

${ }^{16}$ Earlier research has shown that both volatility measures affect the firm's capital structure.

${ }^{17}$ The results of the target leverage model are given in Table $\mathrm{C}$ of Appendix C.
} 
Given the firm-specific target leverage from equation (4), $L^{T}$, we can examine the adjustment speed toward the target using the following model:

$$
L_{i, t}-L_{i, t-1}=\phi\left(L_{i, t}^{T}-L_{i, t-1}\right)+\epsilon_{i, t}
$$

In this model, $L_{i, t}$ is the observed (actual) leverage of firm $i$ in year $t$. The adjustment coefficient $\phi$ measures how quickly firms adjust their capital structure to attain their target leverage. This coefficient should strictly lie between zero and one if there are positive costs of adjustment. When the cost of adjustment is high, the adjustment coefficient would not be statistically different from zero. If the cost of deviating from the target is higher than the cost of adjustment, the adjustment coefficient would be larger, so that the speed of adjustment will be faster.

\subsubsection{Risk and Capital Adjustment: Controlling for Deviations from the Target Leverage}

Equation (5) does not incorporate the effect of risk on the speed of adjustment coefficient. This model also does not allow for asymmetry in adjustment speeds as firms' actual leverage deviates from the target. Here, we introduce both macroeconomic and firm-specific risk to the model while we take into account actual leverage deviations from target leverage. In doing so we address two issues: (i) do firms weigh deviations of actual leverage from their leverage targets differently in times of greater risk? and (ii) does risk have differential effects for firms with above-target leverage and firms with below-target leverage?

If a firm's actual leverage exceeds its target, then the firm can adjust its capital structure to reach its target debt ratio by retiring debt or by issuing new equity. In contrast, if a firm's leverage is below its target, we would expect that the firm can restructure by issuing new debt or repurchasing equity. Yet, the speed with which firms adjust their capital structure will depend on the risk structure of the environment along with whether firms are above or below their target leverage ratio. We expect that firms adjust their leverage asymmetrically, as the risk structure of the environment within which firms operate changes will cause the firm to give different weights to positive and negative deviations of actual leverage from the target. Hence, we modify equation (5) by interacting our risk measures with indicators that 
capture the state of current leverage with respect to target leverage as follows:

$$
\begin{aligned}
L_{i, t}-L_{i, t-1} & =\left(\beta_{1} D_{i, t}^{a b o v}+\beta_{2} D_{i, t}^{\text {belo }}\right) D V T_{i, t}+\left(\beta_{3} D_{i, t}^{a b o v}+\beta_{4} D_{i, t}^{\text {belo }}\right) D V T_{i, t} \times R_{i, t-1}^{\text {firm }} \\
& +\left(\beta_{5} D_{i, t}^{a b o v}+\beta_{6} D_{i, t}^{\text {belo }}\right) D V T_{i t} \times R_{t-1}^{\text {macro }}+v_{i}+\varepsilon_{i, t}
\end{aligned}
$$

where $D V T_{i, t}=L_{i, t}^{T}-L_{i, t-1}$ denotes the deviation of the firm's actual leverage from the target leverage at time $t$, where $L^{T}$ is the predicted value from equation (4). $D_{i, t}^{a b o v}$ is a dummy variable equal to one if the leverage ratio is above the target and zero otherwise for firm $i$ at time $t$. Similarly, $D_{i, t}^{\text {belo }}$ is a dummy variable equal to one if the leverage ratio is below the target and zero otherwise. It may seem that the best time to adjust the capital structure of the firm is when both business and macroeconomic risks are at their lowest. However, given that firms experience different levels of macroeconomic and business risks at each point in time, managers are expected to weigh deviations from target differently as either type of risk varies along with other factors that affect the adjustment process.

\subsubsection{Risk and Capital Adjustment: Controlling for Deviations from the Leverage Target and Financial Imbalances}

According to Myers and Majluf's (1984) pecking order model, there is a hierarchy in firms' financing decisions. Several researchers, among others, including Leary and Roberts (2005) and Strebulaev (2007), empirically show that firms prefer to use internally generated funds (e.g., retained earnings) over external financing and prefer debt over equity. Frank and Goyal (2003) document that an imbalance in cash flows plays a central role in the pecking order. Kayhan and Titman (2007) report that financial deficits have a strong influence on capital structure which is partly reversed over long horizons. They show that the effect of financial status on capital structure is stronger when firms raise capital (i.e., firms have financial deficits) than when firms retire external capital (i.e., firms have financial surpluses). Byoun (2008) proposes a financial needs-induced adjustment framework to investigate how firms adjust their capital structure toward target debt levels. He finds that firms adjust their leverage more rapidly when their leverage is above the target if they experience a financial surplus, or when their leverage is below the target while they experience a financial deficit. 
Given the empirical evidence, it appears that firms are more likely to adjust their capital structure toward their target debt levels when they face imbalances in their cash flows which lead to financial deficits or surpluses. However, this line of research has not yet examined the role of risks for the speed of adjustment. To examine how risk affects the impact of financial conditions on the speed of adjustment for firms with above-target or below-target leverage, we augment equation (6) by incorporating an interaction term between our measures of risk, above-target and below-target indicators, and the financial status of the firm:

$$
\begin{aligned}
L_{i, t}-L_{i, t-1} & =\left(\beta_{1} D_{i, t}^{\text {sur }} D_{i, t}^{\text {abov }}+\beta_{2} D_{i, t}^{\text {def }} D_{i, t}^{\text {abov }}+\beta_{3} D_{i, t}^{\text {sur }} D_{i, t}^{\text {belo }}+\beta_{4} D_{i, t}^{\text {def }} D_{i, t}^{\text {belo }}\right) D V T_{i, t} \\
& +\left(\beta_{5} D_{i, t}^{\text {sur }} D_{i, t}^{\text {abov }}+\beta_{6} D_{i, t}^{\text {def }} D_{i, t}^{\text {abov }}+\beta_{7} D_{i, t}^{\text {sur }} D_{i, t}^{\text {belo }}+\beta_{8} D_{i, t}^{\text {def }} D_{i, t}^{\text {belo }}\right) D V T_{i, t} \times R_{i, t}^{\text {firm }} \\
& +\left(\beta_{9} D_{i, t}^{\text {sur }} D_{i, t}^{\text {abov }}+\beta_{10} D_{i, t}^{\text {def }} D_{i, t}^{\text {abov }}+\beta_{11} D_{i, t}^{\text {sur }} D_{i, t}^{\text {belo }}+\beta_{12} D_{i, t}^{\text {def }} D_{i, t}^{\text {belo }}\right) D V T_{i, t} \times R_{i, t}^{\text {macro }} \\
& +\left(\beta_{13} D_{i, t}^{\text {sur }}+\beta_{14} D_{i, t}^{\text {def }}\right)+v_{i}+\varepsilon_{i, t}
\end{aligned}
$$

As defined earlier, $D V T_{i, t}=L_{i, t}^{T}-L_{i, t-1}$, where $L_{i, t}^{T}$ is the estimated target leverage ratio for firm $i$ at time $t$. $D_{i, t}^{\text {sur }}$ is a dummy variable equal to one if the firm has a financial surplus at time $t$ and zero otherwise, and $D_{i, t}^{d e f}$ is a dummy variable equal to one if the firm has a financial deficit at time $t$ and zero otherwise. The term $v_{i}$ captures firm-specific fixed effects and the term $\varepsilon_{i, t}$ represents the idiosyncratic errors.

We should note that to calculate the imbalances in cash flows (financial deficits/surpluses), we follow Kayhan and Titman (2007) and Byoun (2008) and utilize the cash flow identity

$$
C F_{i, t}-C A P E_{i, t}-\Delta W C_{i, t} \equiv D I V_{i, t}-\Delta d_{i, t}-\Delta e_{i, t}
$$

where $C F_{i, t}$ is the operating cash flow after interest and taxes, $C A P E_{i, t}$ denotes capital expenditures, $\Delta W C_{i, t}$ denotes changes in working capital, $D I V_{i, t}$ denotes payments of dividends, $\Delta d_{i, t}$ is equal to net debt issues and $\Delta e_{i, t}$ denotes net equity issues. ${ }^{18}$ Rearranging

\footnotetext{
${ }^{18}$ Net equity issues are defined as the ratio of the change in book equity minus the change in retained earnings to total assets. Newly retained earnings are the change in balance sheet retained earnings during an accounting year period divided by the book value of total assets. Net debt issues are then defined as the ratio of the change in total assets to total assets less the sum of net equity issues and newly retained earnings.
} 
equation (8), we define a firm's financial deficit $\left(F D_{i, t}\right)$ as:

$$
F D_{i, t}=C A P E_{i, t}+\Delta W C_{i, t}+D I V_{i, t}-C F_{i, t} \equiv \Delta d_{i, t}+\Delta e_{i, t}
$$

Hence, a positive $F D_{i, t}$ implies a financial deficit and a negative value of $F D_{i, t}$ implies a financial surplus.

\section{Empirical Analysis}

Although researchers have used fixed-effects approach to estimate firms' speed of adjustment toward their target leverage, this approach would not be appropriate in a panel data model which incorporates the lagged dependent variable as a regressor. The fixed-effects estimator suffers from a downward 'Nickell bias' on the estimate of the lagged dependent variable's coefficient, leading to overestimation of the speed of adjustment: a particularly serious problem in short panels. ${ }^{19}$ Likewise, the use of first differencing introduces a correlation between the lagged dependent variable and the error, necessitating the use of instrumental variables techniques.

In this paper, we apply the System GMM dynamic panel data estimator. The timeinvariant unobservable firm-specific effects are removed by taking the first difference of each underlying variable as we control for the correlation between the regressors and the errors. In addition, using the System GMM method, we can mitigate the presence of endogeneity by instrumenting differenced equations with lagged levels of the variables and equations in levels with the lags of the first differences of the variables. Last but not the least, the GMM approach allows us to avoid problems that may arise due to the use of generated regressors.

However, in the context of GMM estimation, the use of longer lags may not provide enough additional information, and the use of extra instruments may lead to the problem of many instruments relative to the sample size, which weakens the power of the overidentification test (Roodman (2009)). Here, we confirm the validity of our instruments by implementing the $J$ test of Hansen (1982). We also apply the Arellano-Bond AR(2) test to

\footnotetext{
${ }^{19}$ See Nickell (1981), Bond (2002), and Judson and Owen (1999) for more on related issues.
} 
examine the presence of second-order serial correlation in the residuals. These diagnostic test statistics along with the number of firms and the firm-year observations are reported in Panel B of each table that we present below. For all cases, the $J$ statistics show that the instruments used for the System GMM estimator are valid and satisfy the orthogonality conditions. Also, the serial correlation tests do not detect second-order serial correlation in the residuals. For brevity, we do not comment further on these diagnostics.

\subsection{Risk Effects After Controlling for Deviations from the Target Leverage}

Table 3 presents the results for equation (6) where we first set both risk measures to zero to obtain a benchmark. The results for this specification are given under Model 1. The benchmark results show that firms with above-target leverage $\left(D V T_{i, t} \times D_{i t}^{a b o v}\right)$ adjust their capital structure faster than firms with below-target leverage $\left(D V T_{i, t} \times D_{i t}^{b e l o}\right)$. These findings for UK firms are in line with those of Byoun (2008), who considers US firms.

Model 2 incorporates the effect of risk into the baseline specification and shows that both firm-specific and macroeconomic risks have asymmetric effects on the speed of adjustment, depending on whether the firm's actual leverage exceeds or falls short of the target leverage. The impact of firm-specific risk interacted with the below-target indicator $\left(D V T_{i, t} \times D_{i, t}^{\text {belo }} \times\right.$ $\left.R_{i, t-1}^{f i r m}\right)$ is negative and statistically significant. This implies that an increase in firm-level risk deters firms from adjusting their capital structure toward their targets. In contrast, the impact of firm-specific risk when actual leverage is above-target $\left(D V T_{i, t} \times D_{i, t}^{a b o v} \times R_{i, t-1}^{f i r m}\right)$ is positive, but not statistically significant. Thus, firm-specific risk accelerates the capital structure adjustment process only when the firm's actual leverage lies above the target.

Macroeconomic risk has also a significant role regardless of whether the firm's actual leverage is above or below the target. We find that macroeconomic risk has a negative impact on the adjustment speed of firms with above-target leverage $\left(D V T_{i, t} \times D_{i, t}^{a \text { abov }} \times R_{t-1}^{\text {macro }}\right)$, whereas, it has a positive effect on the adjustment process of firms with below-target leverage $\left(D V T_{i, t} \times D_{i, t}^{\text {belo }} \times R_{t-1}^{\text {macro }}\right)$. Firms with actual leverage above (below) the target are likely to adjust their leverage more slowly (more quickly) toward the target in periods when macroeconomic risk is high. 


\subsubsection{The Speed of Adjustment controlling for Deviations from the Target Leverage}

Using the estimates given in Table 3, we compute the speed of adjustment when risk takes on high, medium, and low levels for firms with above- and below-target leverage and report these values along their standard errors in Table $4 .{ }^{20}$ The adjustment speeds are statistically different from zero for each firm category and vary as both types of risk change when firms' actual leverage is above or below the target leverage. It should also be noted that the speed of adjustment when there is risk is different from that computed for the benchmark model with no risk. This suggests that omission of risk factors in estimating the adjustment of the firms' capital structure leads to biased results.

Inspecting Table 4, we see that the speed of adjustment for the benchmark model with above target leverage, at $32.2 \%$, is greater (yielding a lower half-life) than the remaining cases when risk is introduced. In fact, the table presents an interesting ordering of the speed of adjustment estimates as risk takes on different levels. The speed of adjustment is highest (i.e., lowest half-life) when macroeconomic risk is low. There is a monotonic increase as firm-specific risk increases from low to medium and high levels within each level of macroeconomic risk. This observation accords with intuition. As macroeconomic risk increases, a firm will find it harder to adjust its capital structure, for retiring debt will be costlier in such circumstances due to increased asymmetric information problems.

The estimated speed of adjustment for firms with below-target leverage is around $24.7 \%$ per year for the benchmark model. Adjustment is faster when firm-specific risk is low than when it is high.

On the whole, the estimates given in Table 4 show that firms adjust their actual leverage toward their targets at different speeds as they face different levels of risk when the actual leverage is above or below their target levels. That is, firms consider the levels of firm-specific and macroeconomic risk as well as positive and negative deviations of actual leverage from

\footnotetext{
${ }^{20}$ The standard errors associated with adjustment speed estimate are estimated and reported in the table to test whether the estimated speed of adjustment statistically differs from zero. We compute these standard errors by taking partial derivatives of the estimated equation (6) with respective to $D V T_{i, t}$, which is the deviation of observed (actual) leverage from the target leverage.
} 
the target when adjusting their capital structure.

\subsection{Risk Effects After Controlling for Deviations from the Leverage Target and Financial Imbalances}

Table 5 provides the results for two models based on equation (15) as we incorporate the role of financial imbalances along with deviation of leverage from the target on the adjustment of capital structure: while the benchmark Model 1 excludes both types of risk, Model 2 includes them.

\section{Model 1: The Benchmark}

The benchmark model provides evidence that UK manufacturing firms increase their

leverage whether they face a financial deficit or surplus, as the coefficients of $D_{i, t}^{\text {sur }}$ and $D_{i, t}^{d e f}$ are both positive. This is in line with the statistics provided in Table 1, which show that firm leverage in the UK has been increasing over the period of investigation. According to the benchmark model, firms with a financial surplus tend to increase their leverage more than those that experience a financial deficit. This observation is in contrast to that of Byoun (2008), who shows that US manufacturing firms with a financial surplus reduce their leverage. An inspection of the data shows that the increase in leverage in the UK is due to issuance of new debt instruments rather than equity repurchases.

Next, we examine the coefficient estimates of the interaction terms between firms' financial status (financial surpluses/deficits) and above- and below-target indicators. The coefficient estimates for $D_{i, t}^{\text {sur }} \times D V T_{i, t} \times D_{i, t}^{\text {abov }}$ and that of $D_{i, t}^{d e f} \times D V T_{i, t} \times D_{i, t}^{a b o v}$ are both positive and statistically significant, while the former is significantly larger. This implies that firms whose actual leverage is above the target adjust their capital structure toward the target relatively faster when they have a financial surplus than when they face a financial deficit. The estimate of the coefficient on the interaction between firms' financial deficits and below-target leverage $\left(D_{i, t}^{\text {def }} \times D V T_{i, t} \times D_{i, t}^{\text {belo }}\right)$ is positive and statistically significant but smaller in magnitude than that of above-target leverage, regardless of the financial status of the firm. Firms experiencing financial deficits with below-target leverage adjust their leverage, but at a lower speed than those with above-target leverage. Interestingly, we also 
find that firms with a financial surplus do not strive to revert to the target level when their leverage is below target. Rather, these firms further deviate from the target, as the coefficient estimate on the financial surplus with below-target interaction $\left(D_{i, t}^{\text {sur }} \times D V T_{i, t} \times D_{i, t}^{\text {belo }}\right)$ is negative and statistically significant.

The results from our benchmark model provide evidence that capital structure adjustments are asymmetric and related to firms' cash flow imbalances as well as the stance of firms' actual leverage versus their target leverage. In Model 2 below, we explore whether the introduction of the firm-specific and macroeconomic risk interaction terms into the benchmark model would reveal further asymmetries in the leverage adjustment process.

\section{Model 2: A. The Asymmetric Impact of Firm-Specific Risk}

Before interpreting the effects of risk on adjustment speeds it would be useful to statistically test the relevance of both firm-specific and macroeconomic risk in explaining asymmetries in speed of adjustment. To perform this, we impose the parametric restriction on the estimated coefficient of interaction terms between both types of risks and firms' financial status (financial surpluses/deficits) and above- and below-target indicators: that is, $H_{0}: \beta_{5}=\beta_{6}=\beta_{7}=\beta_{8}=\beta_{9}=\beta_{10}=\beta_{11}=\beta_{12}=0$. The estimated value of F-statistic $(\mathrm{F}$-stat $=11.63 ; \mathrm{p}$-value $=0.000)$ provides significant evidence of the rejection of the null hypothesis. ${ }^{21}$ This implies that firm-specific as well as macroeconomic risk factors are relevant for capital structure adjustment decisions of firms. The restriction test results as well as the estimated coefficients are in agreement with the proposed hypotheses, as the p-values are less than 0.05 for seven out of eight estimated coefficients.

Turning to the influence of risk on adjustment, we find that the effect of firm-specific risk on firms with a financial surplus and above-target leverage $\left(D_{i, t}^{\text {sur }} \times D V T_{i, t} \times D_{i, t}^{a b o v e} \times R_{t-1}^{\text {firm }}\right)$ is negative and statistically significant. Firms enjoying a financial surplus with above-target leverage slow down their capital adjustment when firm-specific risk is high. Hence, we expect

\footnotetext{
${ }^{21} \mathrm{We}$ also test the relevance of firm-specific and macroeconomic risk in estimating the adjustment of firms' leverage separately. In both cases, we reject the linear restriction on the parameters, as the p-values are less than 0.05 , suggesting the importance of both types of risks in adjustment of the firm's capital structure.
} 
that firms with above-target leverage and financial surpluses use their surplus to reduce their outstanding debt when these firms are more certain about their expected future cash flows. In contrast, the effect of firm-specific risk on firms that have financial deficits with above-target leverage $\left(D_{i, t}^{\text {def }} \times D V T_{i, t} \times D_{i, t}^{a b o v e} \times R_{t-1}^{\text {firm }}\right)$ is positive and significant. Firms with abovetarget leverage experiencing a financial deficit are more likely to issue equity to finance their financial deficits when they experience periods of high firm-specific risk. As debt becomes relatively more expensive for risky firms when banks and other financial institutions charge higher risk premiums, these firms tend to prefer equity over debt financing.

For firms with financial surpluses and below-target leverage, we find that the variable $\left(D_{i, t}^{\text {sur }} \times D V T_{i, t} \times D_{i, t}^{\text {belo }} \times R_{t-1}^{\text {firm }}\right)$ has a positive coefficient, implying that an increase in firm-level risk leads to an increase in the speed of adjustment toward the level of target leverage. This suggests that below-target firms with financial surpluses tend to repurchase their equity in periods when they experience high firm-specific risk. These firms move their leverage toward the target by reducing their outstanding external financing. The effect of firm-specific risk on firms with financial deficits and below-target leverage $\left(D_{i, t}^{\text {def }} \times D V T_{i, t} \times D_{i, t}^{\text {belo }} \times R_{t-1}^{\text {firm }}\right)$ is negative, so that these firms slow their capital adjustment process when firm-specific risk is high. They are more likely to attain their target leverage by issuing debt when firm-specific risk is low. Firms do so because they face fewer debt-related problems, such as an increased likelihood of bankruptcy, in periods of low firm-specific risk.

\section{Model 2: B. The Asymmetric Impact of Macroeconomic Risk}

The estimated impacts of macroeconomic risk on the change in leverage when firms experience financial deficits with above-target leverage $\left(D_{i, t}^{\text {def }} \times D V T_{i, t} \times D_{i, t}^{\text {above }} \times R_{t-1}^{\text {macro }}\right)$ and that for firms with financial deficits and below-target $\left(D_{i, t}^{\text {def }} \times D V T_{i, t} \times D_{i, t}^{\text {belo }} \times R_{t-1}^{\text {macro }}\right)$ are both negative and statistically significant. In other words, firms in these two groups adjust their leverage toward their targets faster in periods when macroeconomic risks are low. Firms facing financial deficits with above-target (below-target) leverage are more likely to finance their financial deficits and adjust their leverage to the target by issuing equity (debt) when macroeconomic risks are low. Firms with financial deficits, regardless of whether 
their observed leverage is below or above the target, may face low adjustment costs when macroeconomic conditions are stable and certain, encouraging adjustments in their capital structure.

In cases where firms have a financial surplus along with above-target leverage, the effect of macroeconomic risk on the change in leverage $\left(D_{i, t}^{s u r} \times D V T_{i, t} \times D_{i, t}^{\text {above }} \times R_{t-1}^{\text {macro }}\right)$ is positive and statistically significant. These firms adjust their leverage more rapidly in periods of higher macroeconomic risk. This finding is in line with the fact that high levels of outstanding debt tend to expose firms to macroeconomic shocks and, as a result, firms are more likely to reduce their use of debt during volatile states of the economy. Last but not least, we find that the effect of macroeconomic risk on the change in leverage when firms have a financial surplus with below-target leverage $\left(D_{i, t}^{\text {sur }} \times D V T_{i, t} \times D_{i, t}^{\text {belo }} \times R_{t-1}^{\text {macro }}\right)$ is positive, suggesting that such firms use their financial surpluses to repurchase existing equity in order to reduce overall external financing when macroeconomic risks are high.

The results given in Table 5 provide evidence that asymmetric speeds of adjustment are related to risk, above and beyond the state of the firm's leverage and its financial imbalances. Further, the results suggest that both firm-specific and macroeconomic risks have differential effects on capital structure adjustment decisions of firms. Therefore, we argue that omission of these factors will yield biased conclusions on capital structure adjustments.

\subsubsection{The Speed of Adjustment controlling for Financial Imbalances and Deviations from Target Leverage}

We now consider the speed of adjustment toward the leverage target, allowing risk to vary across low, medium, and high levels. We compute the adjustment speed and the corresponding half-life in four-way interactions with respect to financial imbalances of the firm (financial deficits/surpluses) and the positive or negative deviation of actual leverage from the target. For each sub-panel, we also compute the adjustment speed and the corresponding half-life when both types of risks are set to zero. The results given in Table 6 show that firms' speed of adjustment toward the target leverage changes significantly as the level of risk varies. 
Sorting by the speeds of adjustment, we see that firms with a financial surplus and abovetarget leverage adjust their capital structure more quickly when macroeconomic risk is high; the speed of adjustment falls with a decline in macroeconomic risk. Although an increase in firm-specific risk slows down the adjustment process, its impact is minor compared to that of macroeconomic risk. For instance, when macroeconomic risk is high and firm-specific risk is low (high), the estimated speed of adjustment is $82.5 \%$ (80.6\%). Firms that enjoy a financial surplus with above-target leverage reduce their outstanding debt more quickly as macroeconomic risk increases to escape from the financial distress. Also note that the speed of adjustment for this category of firms is significantly faster than the benchmark case.

When we compute the speed of adjustment for firms that have financial surpluses with below-target leverage, we observe an interesting phenomenon: (i) these firms deviate from their target leverage when there is zero risk, and (ii) these firms do not significantly adjust their capital structure when they experience risk. In general, the estimated adjustment speeds for these firms are negative but not statistically different from zero. Given that these firms experience financial surplus, we argue that firms' managers choose the option to wait before adjusting their firms' capital structure when the environment is risky.

We next examine the capital structure adjustment of those firms that have financial deficits with above-target leverage. We see that these firms have the highest speed of adjustment coefficient (the lowest half-life estimate) when we set both types of risk to zero. Once we incorporate the effects of risk, the adjustment coefficient size changes dramatically. These firms adjust most quickly when macroeconomic risk is low and when firm-specific risk is high, with the slowest adjustment occurring when macroeconomic risk is high and firm-specific risk is low. A potential explanation behind this observation is that as the adjustment process requires issuing equity in the presence of a financial deficit, changing the capital structure in a risky environment is not a trivial process. ${ }^{22}$ As a consequence, the speed of adjustment in a risky environment is significantly slower in comparison to the benchmark model.

\footnotetext{
${ }^{22}$ Unpredictable variations in macroeconomic conditions may cause rapid variations in firms' market value, rendering the issuance of equity an unattractive source of finance for managers.
} 
The last case includes firms that have financial deficits with below-target leverage. We observe that such firms adjust most rapidly when both firm-specific and macroeconomic risks are low, with an estimated speed of adjustment of less than $30 \%$ per year. We also find that the fastest adjustment takes places when both types of risk are low, with the speed of adjustment falling to at $24 \%$ per year. Because firms in this group must issue new debt to raise funds, they can do so more easily when they are relatively more certain about their potential cash flow stream and when macroeconomic prospects are favorable. This is in line with the fact that firms are less cautious about the cost of financial distress and bankruptcy in periods of low risk, and thus, they tend to increase their use of debt. Here, too, the difference in the speed of adjustment between the benchmark and the other cases is significant.

Overall, the results in Tables 5 and 6 provide evidence that firms' adjustment speeds are affected asymmetrically with respect to either type of risk while we control for their financial imbalances and deviations of actual leverage from the target. Risk accelerates the speed of adjustment for firms with a financial surplus and above-target leverage and retards the speed of adjustment for firms with a financial deficit and below-target leverage.

These observations are of interest because they suggest that the differences in the adjustment speeds are not fully explained by the imbalances of firms' cash flows nor by deviations from a leverage target: they are also significantly affected by the levels of firm-specific and macroeconomic risk. In other words the introduction of both types of risk factors into the model has a significant impact on our estimates. Hence, our findings are useful in interpreting earlier research which questions why firms are not always responsive to changes in the market value of their equity (Welch (2004)) or gains and losses in their earnings (Hovakimian et al. (2004)) and why they are sensitive to debt and equity market conditions when financing external capital (Baker and Wurgler (2002) and Antoniou et al. (2009)).

\subsection{Robustness Checks}

To check the robustness of our results, we estimate five different specifications as we consider i) target leverage estimates without risk factors, ii) an alternative definition of 
leverage measured by total debt/total assets, iii) generating the firm-specific risk measure after controlling for effects of macroeconomic conditions, iv) alternative measures of risk, and v) target leverage based on historical leverage.

Table 7 provides the results when we use the target leverage estimated without including firm-specific and macroeconomic risk into the specification. We then estimate equation (15). One can observe that the results presented in the table are similar to our earlier findings. In particular, we observe that firms with a financial surplus and above-target leverage adjust their capital structure towards the target faster when they face risk, whereas, firms with a financial deficit and below-target leverage slow down their adjustment process when they face risk.

Table 8 provides the results when we use the ratio of total debt (short-term debt + long-term debt) to total assets as a measure of leverage rather than our broader measure of leverage. ${ }^{23}$ The estimated adjustment speeds are similar to those presented in Table 6. Specifically, we observe that firms with a financial surplus and above-target leverage adjust their capital structure towards the target faster when firm-specific risk is low and macroeconomic risk is high. Yet, firms with a financial deficit and below-target leverage change their capital structure when both types of risk are set to zero. We also observe that firms with a financial deficit and above-target leverage do not significantly adjust their capital structure towards their target when macroeconomic risk is high. These results indicate that our initial observations that asymmetries in adjustment speed are attributed to the type of risk and its magnitude even after controlling for firms' current leverage and their financial position are robust to the use of a narrower leverage measure.

We also check the robustness of risk effects on the estimated speed of adjustment by considering a macroeconomic conditions-adjusted firm-specific risk measure. To generate

\footnotetext{
${ }^{23}$ We consider this narrow measure of leverage as an alternative measure because most of the previous studies in the empirical capital structure literature have utilized this measure (e.g., see Ozkan (2001), Flannery and Rangan (2006), and Dang et al. (2012) ). However, it should be noted that the broader leverage measure has also been used by several researchers in the literature including Iliev and Welch (2010), Chang and Dasgupta (2009), and Kayhan and Titman (2007).
} 
this new measure of firm-specific risk, we augment the sales specification in equation (1) by including the log of real GDP and CPI as additional explanatory variables to control for macroeconomic conditions. We do this because one may argue that the firm-specific risk measure obtained from a simple AR model (see equation (1)) for sales may not reflect the true firm-specific risks as the sales of a firm depend on macroeconomic conditions as well. The estimated adjustment speeds with this macroeconomic conditions-adjusted firm-specific risk, given in Table 9, are, similar to those presented in Table 6. The results from this investigation further confirm the robustness of our findings.

Finally, we check the robustness of our findings by using the historical mean of the firm leverage as a proxy for the firm's target leverage ratio in our estimation and alternative measures of firm-specific and macroeconomic risk. In doing so, we use cash flow volatility as an alternative firm-specific risk, which is also utilized by Lemmon et al. (2008) and Leary and Roberts (2005). In carrying out this examination, we used a consumer price index based volatility measure as an alternative proxy for macroeconomic risk. The results, which we provide in Table 10, are similar to our earlier findings. Hence, we suggest that the effects of risks on capital structure adjustments are not driven by the specific measure of risk or the specific target leverage estimate.

\section{Summary and Concluding Remarks}

Despite the evidence that both idiosyncratic and macroeconomic risks affect firms' capital structure, researchers have not fully investigated the effects of risk on the speed with which firms reverse deviations from their target debt ratios. In this paper, we examine the extent to which firm-specific and macroeconomic risks affect capital structure adjustment speeds. We estimate our models using the System GMM dynamic panel data estimator as we focus on a panel of UK manufacturing firms covering the 1981-2009 period.

To examine the impact of risk on the adjustment of firm's capital structure, we first estimate a model that allows firms' actual leverage to exceed or fall short of the target. We then extend this model in the spirit of Byoun (2008), as we examine the impact of risk on 
capital structure adjustment decisions of firms that experience financial imbalances when their actual leverage is above or below the target. For both sets of models, we provide compelling evidence that different levels and types of risk exert asymmetric effects on the firm's capital adjustment process, even after controlling for firms' financial imbalances and the deviations of actual leverage from the target.

To address the robustness of our results we carry out five different specifications as we consider i) target leverage estimates without risk factors, ii) an alternative definition of leverage measured by total debt/total assets, iii) generating the firm-specific risk measure after controlling for effects of macroeconomic conditions, iv) alternative measures of risk, and v) target leverage based on historical leverage. The results from all five specifications are largely similar to our main findings, supporting the view that both firm-specific and macroeconomic risks play a significant role in the adjustment of firms' capital structure.

Overall, our results help us understand why firms may not aggressively act to offset the effects of changes in their market value of equity or earnings, as it is clear that managers must carefully consider both the overall state of the economy and their own business activities as well as the associated risks. Our results also provide evidence that the omission of risk factors in examining the adjustment of firms' capital structure will lead to biased conclusions. We believe that further research along these lines across broader samples of firms would improve our understanding on the impact of risk on the dynamic adjustment process of firms' capital structure. 
Akhtar, S. Capital structure and business cycles. Accounting \& Finance 52(1), 25-44.

Almeida, H. and M. Campello (2010). Financing frictions and the substitution between internal and external funds. Journal of Financial and Quantitative Analysis 45(3), 589622.

Alti, A. (2006). How persistent is the impact of market timing on capital structure? Journal of Finance 61(4), 1681-1710.

Antoniou, A., Y. Guney, and K. Paudyal (2008). The determinants of capital structure: Capital market-oriented versus bank-oriented institutions. Journal of Financial and Quantitative Analysis 43(1), 59-92.

Antoniou, A., H. Zhao, and B. Zhou (2009). Corporate debt issues and interest rate risk management: Hedging or market timing? Journal of Financial Markets 12(3), 500-520.

Baker, M. and J. Wurgler (2002). Market timing and capital structure. Journal of Finance 57(1), 1-32.

Baum, C. F., A. Stephan, and O. Talavera (2009). The effects of uncertainty on the leverage of nonfinancial firms. Economic Inquiry 47(2), 216-225.

Baxter, N. D. (1967). Leverage, risk of ruin and the cost of capital. Journal of Finance 22(3), $395-403$.

Bernanke, B. and M. Gertler (1989). Agency costs, net worth, and business fluctuations. American Economic Review 79(1), 14-31.

Bhamra, H. S., L. A. Kuehn, and I. A. Strebulaev (2010). The aggregate dynamics of capital structure and macroeconomic risk. Review of Financial Studies 23(12), 4187-4241.

Bo, H. (2002). Idiosyncratic uncertainty and firm investment. Australian Economic Papers $41(1), 1-14$.

Bond, S. (2002). Dynamic panel data models: A guide to micro data methods and practice. Portuguese Economic Journal 1(2), 141-162.

Bradley, M., G. A. Jarrell, and E. H. Kim (1984). On the existence of an optimal capital structure: Theory and evidence. Journal of Finance 39(3), 857-878.

Brav, O. (2009). Access to capital, capital structure, and the funding of the firm. Journal of Finance 64 (1), 263-308.

Brealey, R. A. and S. Myers (1981). Principles of corporate finance. Tata McGraw-Hill.

Byoun, S. (2008). How and when do firms adjust their capital structures toward targets? Journal of Finance 63(6), 3069-3096.

Caglayan, M. and A. Rashid (2014). The response of firms' leverage to uncertainty: Evidence from UK public versus non-public firms. Economic Inquiry 52(1), 341-363.

Calomiris, C. W. and R. G. Hubbard (1990). Firm heterogeneity, internal finance, and credit rationing. Economic Journal 100(399), 90-104. 
Castanias, R. (1983). Bankruptcy risk and optimal capital structure. Journal of Finance 38(5), 1617-1635.

Chang, X. and S. Dasgupta (2009). Target behavior and financing: How conclusive is the evidence? Journal of Finance 64(4), 1767-1796.

Chen, H. (2010). Macroeconomic conditions and the puzzles of credit spreads and capital structure. Journal of Finance 65(6), 2171-2212.

Choe, H., R. W. Masulis, and V. Nanda (1993). Common stock offerings across the business cycle: Theory and evidence. Journal of Empirical Finance 1(1), 3-31.

Cook, D. O. and T. Tang (2010). Macroeconomic conditions and capital structure adjustment speed. Journal of Corporate Finance 16(1), 73-87.

Dang, V., M. Kim, and Y. Shin (2012). Asymmetric capital structure adjustments: New evidence from dynamic panel threshold models. Journal of Empirical Finance 19(2), $465-482$.

Drobetz, W., P. Pensa, and G. Wanzenried (2007). Firm characteristics, economic conditions and capital structure adjustments. Working paper 16/07, Wirtschaftswissenschaftliches Zentrum (WWZ) Der Universitate Basel.

Drobetz, W. and G. Wanzenried (2006). What determines the speed of adjustment to the target capital structure? Applied Financial Economics 16(13), 941-958.

Elsas, R. and D. Florysiak (2010). Dynamic capital structure adjustment and the impact of fractional dependent variables. Working paper, University of Munich.

Elsas, R. and D. Florysiak (2011). Heterogeneity in the speed of adjustment toward target leverage. International Review of Finance 11(2), 181-211.

Fama, E. F. and K. R. French (2002). Testing trade-off and pecking order predictions about dividends and debt. Review of Financial Studies 15(1), 1-33.

Faulkender, M., M. J. Flannery, K. W. Hankins, and J. M. Smith (2012). Cash flows and leverage adjustments. Journal of Financial Economics 103(3), 632-646.

Ferri, M. G. and W. H. Jones (1979). Determinants of financial structure: A new methodological approach. Journal of Finance 34 (3), 631-644.

Fisher, L. (1959). Determinants of risk premiums on corporate bonds. Journal of Political Economy 67(3), 217-237.

Flannery, M. J. and K. W. Hankins (2007). A theory of capital structure adjustment speed. Working paper, University of Florida and University of Kentucky.

Flannery, M. J. and K. P. Rangan (2006). Partial adjustment toward target capital structures. Journal of Financial Economics 79(3), 469-506.

Frank, M. Z. and V. K. Goyal (2003). Testing the pecking order theory of capital structure. Journal of Financial Economics 67(2), 217-248. 
Gertler, M. (1992). Financial capacity and output fluctuations in an economy with multiperiod financial relationships. Review of Economic Studies 59(3), 455-472.

Gertler, M. and S. Gilchrist (1993). The role of credit market imperfections in the monetary transmission mechanism: Arguments and evidence. Scandinavian Journal of Economics 95(1), 43-64.

Gertler, M. and S. Gilchrist (1994). Monetary policy, business cycles, and the behavior of small manufacturing firms. Quarterly Journal of Economics 109(2), 309-340.

Gertler, M. and R. G. Hubbard (1993). Corporate financial policy, taxation, and macroecononmic risk. Rand Journal of Economics 24 (2), 286-303.

Greenwald, B. C. and J. E. Stiglitz (1993). Financial market imperfections and business cycles. Quarterly Journal of Economics 108(1), 77-114.

Haas, R. and M. Peeters (2006). The dynamic adjustment towards target capital structures of firms in transition economies. Economics of Transition 14(1), 133-169.

Hansen, L. P. (1982). Large sample properties of generalized method of moments estimators. Econometrica 50(4), 1029-1054.

Hatzinikolaou, D., G. M. Katsimbris, and A. G. Noulas (2002). Inflation uncertainty and capital structure: Evidence from a pooled sample of the Dow-Jones industrial firms. International Review of Economics 85 Finance 11(1), 45-55.

Hovakimian, A., G. Hovakimian, and H. Tehranian (2004). Determinants of target capital structure: The case of dual debt and equity issues. Journal of Financial Economics 71 (3), $517-540$.

Huang, R. and J. R. Ritter (2009). Testing theories of capital structure and estimating the speed of adjustment. Journal of Financial and Quantitative Analysis 44(2), 237-271.

Iliev, P. and I. Welch (2010). Reconciling estimates of the speed of adjustment of leverage ratios. Working paper, Brown University.

Jalilvand, A. and R. Harris (1984). Corporate behavior in adjusting to capital structure and dividend targets: An econometric study. Journal of Finance 39(1), 127-145.

Judson, R. and A. Owen (1999). Estimating dynamic panel data models: A guide for macroeconomists. Economics Letters 65(1), 9-15.

Kayhan, A. and S. Titman (2007). Firms' histories and their capital structures. Journal of Financial Economics 83(1), 1-32.

Kiyotaki, N. and J. Moore (1997). Credit cycles. Journal of Political Economy 105(2), $211-248$.

Korajczyk, R. A. and A. Levy (2003). Capital structure choice: Macroeconomic conditions and financial constraints. Journal of Financial Economics 68(1), 75-109.

Leary, M. T. and M. R. Roberts (2005). Do firms rebalance their capital structures? Journal of Finance 60(6), 2575-2619. 
Lemmon, M. L., M. R. Roberts, and J. F. Zender (2008). Back to the beginning: Persistence and the cross-section of corporate capital structure. Journal of Finance 63(4), 1575-1608.

Marsh, P. (1982). The choice between equity and debt: An empirical study. Journal of Finance $37(1), 121-144$.

Modigliani, F. and M. H. Miller (1958). The cost of capital, corporation finance and the theory of investment. American Economic Review 48(3), 261-297.

Myers, S. C. and N. S. Majluf (1984). Corporate financing and investment decisions when firms have information that investors do not have. Journal of Financial Economics 13(2), $187-221$.

Nickell, S. (1981). Biases in dynamic models with fixed effects. Econometrica 49(6), 14171426.

Ozkan, A. (2001). Determinants of capital structure and adjustment to long run target: Evidence from UK company panel data. Journal of Business Finance 86 Accounting 28(12), 175-198.

Öztekin, Ö. and M. J. Flannery (2012). Institutional determinants of capital structure adjustment speeds. Journal of Financial Economics 103(1), 88-112.

Roodman, D. (2009). A note on the theme of too many instruments. Oxford Bulletin of Economics and Statistics 71(1), 135-158.

Shyam-Sunder, L. and S. C. Myers (1999). Testing static tradeoff against pecking order models of capital structure. Journal of Financial Economics 51(2), 219-244.

Strebulaev, I. A. (2007). Do tests of capital structure theory mean what they say? Journal of Finance 62(4), 1747-1787.

Taub, A. J. (1975). Determinants of the firm's capital structure. Review of Economics and Statistics 57(4), 410-416.

Titman, S. and R. Wessels (1988). The determinants of capital structure choice. Journal of Finance 43(1), 1-19.

Wald, J. K. (1999). How firm characteristics affect capital structure: An international comparison. Journal of Financial Research 22(2), 161-187.

Welch, I. (2004). Capital structure and stock returns. Journal of Political Economy 112(1), 106-131.

$\mathrm{Xu}, \mathrm{Z}$. (2007). Do firms adjust toward a target leverage level? Working paper, Bank of Canada. 


\section{Table 1: Summary Statistics of Firm-Specific Factors}

The second, third and fourth columns report the firm-year observations (N), mean and standard deviation (S.D.) of the firmspecific variables, respectively. The last three columns report the $25^{t h}, 50^{t h}$ and $75^{t h}$ percentiles of the firm-specific variables. The variables are defined as follows. Book leverage is the ratio of the book value of total debt to the book value of total assets. The market-to-book value ratio is defined as the book value of total assets less the book value of equity plus the market value of equity divided by the book value of total assets. Investment is the ratio of total expenditures to purchase fixed tangible assets to the total book assets. Profitability is the ratio of earnings before interest, taxes, and depreciation to the total book assets. Tangibility is defined as the ratio of net plant, property, and equipment to the total book assets. The two-year stock return is the percentage change between share prices at time $t$ and share prices at time $t-2$. Firm size is defined as the logarithm of net sales. The non-debt tax shield is defined as total depreciation expense divided by the book value of total assets. The sample consists of all UK manufacturing firms listed on the London Stock Exchange at any point over the period 1981-2009. The data are drawn from the WorldScope Global database via DataStream.

\begin{tabular}{|c|c|c|c|c|c|c|}
\hline Variables & $\mathrm{N}$ & Mean & S.D. & $\mathrm{P} 25$ & Median & P75 \\
\hline \multicolumn{7}{|c|}{ Book Leverage } \\
\hline $1981-90$ & 1546 & 0.506 & 0.176 & 0.401 & 0.504 & 0.608 \\
\hline $1991-2000$ & 4387 & 0.556 & 0.317 & 0.379 & 0.522 & 0.661 \\
\hline 2001-09 & 7841 & 0.598 & 0.568 & 0.332 & 0.509 & 0.689 \\
\hline 1981-2009 & 13774 & 0.574 & 0.469 & 0.358 & 0.513 & 0.669 \\
\hline \multicolumn{7}{|c|}{ Market-to-Book Value } \\
\hline $1981-90$ & 1434 & 1.491 & 0.773 & 1.005 & 1.279 & 1.722 \\
\hline $1991-2000$ & 4171 & 2.241 & 2.691 & 1.095 & 1.528 & 2.242 \\
\hline 2001-09 & 7120 & 1.987 & 1.807 & 1.033 & 1.424 & 2.178 \\
\hline 1981-2009 & 12725 & 2.014 & 2.077 & 1.047 & 1.437 & 2.136 \\
\hline \multicolumn{7}{|l|}{ Investment } \\
\hline $1981-90$ & 1917 & 0.084 & 0.062 & 0.042 & 0.066 & 0.107 \\
\hline $1991-2000$ & 4456 & 0.066 & 0.059 & 0.028 & 0.051 & 0.083 \\
\hline 2001-09 & 7766 & 0.049 & 0.062 & 0.012 & 0.029 & 0.059 \\
\hline $1981-2009$ & 14139 & 0.059 & 0.063 & 0.018 & 0.041 & 0.076 \\
\hline \multicolumn{7}{|c|}{ Profitability } \\
\hline $1981-90$ & 1904 & 0.166 & 0.087 & 0.117 & 0.161 & 0.211 \\
\hline $1991-2000$ & 4425 & 0.096 & 0.257 & 0.073 & 0.137 & 0.197 \\
\hline 2001-09 & 7852 & 0.001 & 0.399 & -0.007 & 0.097 & 0.164 \\
\hline 1981-2009 & 14181 & 0.053 & 0.337 & 0.049 & 0.121 & 0.184 \\
\hline \multicolumn{7}{|c|}{ Two-year Stock Return } \\
\hline $1981-90$ & 1421 & 0.283 & 1.187 & -0.442 & 0.288 & 0.873 \\
\hline $1991-2000$ & 3932 & 0.427 & 1.351 & -0.439 & 0.438 & 1.236 \\
\hline 2001-09 & 6715 & -0.134 & 1.722 & -1.171 & 0.113 & 1.072 \\
\hline 1981-2009 & 12068 & 0.098 & 1.575 & -0.789 & 0.249 & 1.098 \\
\hline \multicolumn{7}{|l|}{ Tangibility } \\
\hline $1981-90$ & 1922 & 0.362 & 0.196 & 0.229 & 0.324 & 0.468 \\
\hline $1991-2000$ & 4460 & 0.348 & 0.228 & 0.176 & 0.311 & 0.459 \\
\hline 2001-09 & 7907 & 0.235 & 0.234 & 0.050 & 0.152 & 0.348 \\
\hline $1981-2009$ & 14289 & 0.287 & 0.235 & 0.090 & 0.243 & 0.417 \\
\hline \multicolumn{7}{|l|}{ Firm Size } \\
\hline $1981-90$ & 1931 & 11.761 & 1.986 & 10.321 & 11.600 & 13.267 \\
\hline $1991-2000$ & 4465 & 11.229 & 2.210 & 9.737 & 11.019 & 12.653 \\
\hline 2001-09 & 7932 & 10.941 & 2.381 & 9.155 & 10.805 & 12.485 \\
\hline 1981-2009 & 14328 & 11.141 & 2.295 & 9.486 & 11.003 & 12.654 \\
\hline \multicolumn{7}{|c|}{ Non-debt Tax Shields } \\
\hline $1981-90$ & 1904 & 0.036 & 0.026 & 0.022 & 0.032 & 0.044 \\
\hline 1991-2000 & 4425 & 0.046 & 0.121 & 0.025 & 0.038 & 0.054 \\
\hline 2001-09 & 7852 & 0.052 & 0.095 & 0.022 & 0.038 & 0.059 \\
\hline 1981-2009 & 14181 & 0.048 & 0.098 & 0.023 & 0.037 & 0.055 \\
\hline
\end{tabular}




\section{Table 2: Summary Statistics of Risk Measures}

The second and third columns report the mean and standard deviation (S.D.) of firm-specific and macroeconomic risk, respectively. The last three columns report the $25^{t h}, 50^{t h}$ and $75^{t h}$ percentiles of the risk measures. Firm-specific risk is constructed using data on firms' sales estimating the following model for each underlying firm:

$$
\text { Sales }_{i, t}=\mu_{i}+\varphi \text { Sales }_{i, t-1}+\zeta_{i t}
$$

where Sales $_{i, t}$ denotes the ratio of sales to the book value of total assets for firm $i$ at time $t, \mu_{i}$ is the constant for firm $i$, $\varphi$ is the autoregressive parameter, and $\zeta_{i, t}$ is the error term with zero mean and finite variance. Residuals are then used to calculate the cumulative variance for each firm. The square root of the cumulative variance is used as a proxy for firm-specific risk.

Macroeconomic risk is proxied by the conditional variance of UK real GDP over the period under investigation. In order to generate the conditional variance, we estimate the following $\mathrm{ARCH}(1)$ model:

$$
\begin{aligned}
\Delta G D P_{t} & =\omega+\eta \Delta G D P_{t-1}+\epsilon_{t} \\
\sigma_{t}^{2} & =\alpha+\beta \epsilon_{t-1}^{2}
\end{aligned}
$$

where $\omega$ is a constant term and $\eta$ is the autoregressive parameter. The estimated conditional variance, $\widehat{\sigma}_{t}^{2}$, is the one-periodahead forecast variance based on prior information. The sample consists of all UK manufacturing firms listed on the London Stock Exchange at any point over the period 1981-2009. The data are drawn from the WorldScope Global database via

\begin{tabular}{|c|c|c|c|c|c|}
\hline Variables & Mean & S.D. & $\mathrm{P} 25$ & Median & P75 \\
\hline \multicolumn{6}{|c|}{ Firm-Specific Risk } \\
\hline $1981-90$ & 0.241 & 0.287 & 0.093 & 0.161 & 0.289 \\
\hline $1991-2000$ & 0.262 & 0.249 & 0.118 & 0.192 & 0.319 \\
\hline $2001-09$ & 0.349 & 0.503 & 0.135 & 0.232 & 0.399 \\
\hline 1981-2009 & 0.309 & 0.418 & 0.124 & 0.212 & 0.359 \\
\hline \multicolumn{6}{|c|}{ Macroeconomic Risk } \\
\hline $1981-90$ & 1.133 & 0.916 & 1.455 & 1.221 & 1.458 \\
\hline $1991-2000$ & 1.328 & 0.385 & 1.013 & 1.323 & 1.411 \\
\hline 2001-09 & 1.884 & 1.403 & 1.189 & 1.556 & 2.172 \\
\hline 1981-2009 & 1.779 & 1.002 & 1.172 & 1.440 & 1.958 \\
\hline
\end{tabular}
DataStream. Quarterly data spanning 1975Q1-2009Q4 on seasonally adjusted UK real GDP are taken from the Office for National Statistics (ONS) database (Pn: A2: ABMI: Gross Domestic Product: chained volume measure). 
Table 3: Effects of Risk on the Speed of Adjustment while Controlling for Deviations from the Target Leverage

Table 3 reports the robust two-step system-GMM estimation results of the impact of risk on the marginal effects of deviations from the target leverage ratio on the adjustment speed for the following model:

$$
\begin{aligned}
L_{i, t}-L_{i, t-1} & =\left(\beta_{1} D_{i, t}^{a b o v}+\beta_{2} D_{i, t}^{\text {belo }}\right) D V T_{i, t}+\left(\beta_{3} D_{i, t}^{a b o v}+\beta_{4} D_{i, t}^{\text {belo }}\right) D V T_{i, t} \cdot R_{i, t-1}^{\text {firm }} \\
& +\left(\beta_{5} D_{i, t}^{a b o v}+\beta_{6} D_{i, t}^{\text {belo }}\right) D V T_{i, t} . R_{t-1}^{\text {macro }}+v_{i}+\varepsilon_{i, t}
\end{aligned}
$$

where $L_{i, t}$ is a measure of leverage for firm $i$ in year $t . D V T_{i, t}$ is the deviation of observed (actual) leverage from the target leverage ratio for firm $i$ at time $t, D_{i, t}^{a b o v}$ is a dummy variable equal to one if the leverage ratio is above the target and zero otherwise for firm $i$ at time $t, D_{i, t}^{\text {belo }}$ is a dummy variable equal to one if the leverage ratio is below the target and zero otherwise for firm $i$ at time $t, R_{i, t}^{\text {firm }}$ is a measure of time-varying firm-specific risk and $R_{t}^{\text {macro }}$ is a measure of time-varying macroeconomic risk. Firm-specific risk is drawn from the sales of firms. Macroeconomic risk is proxied by the conditional variance of UK real GDP over the period under investigation. Model 1, a modified standard adjustment model of capital structure, reflects our baseline specifications where the firm capital structure adjustments are interacted with above- and below-target leverage indicators. Model 2 reflects the interactions among the firm's capital structure adjustments, aboveand below-target leverage indicators, and our measures of risk. The sample consists of all UK manufacturing firms listed on the London Stock Exchange at any point over the period 1981-2009. The data are drawn from the WorldScope database via DataStream. Panel B of the table reports the number of firms, the firm-year observations, the $J$ statistics, which is a test of the over identifying restrictions, the Arellano-Bond test, $\operatorname{AR}(2)$, for second-order autocorrelation in the first-differenced residuals, and firm-year observations. ${ }^{* * *}$ and ${ }^{* *}$ denote statistical significance at the $1 \%$ and $5 \%$

\begin{tabular}{|c|c|c|c|c|}
\hline \multicolumn{5}{|c|}{ Panel A: Estimation Results; Dependent Variable: $\Delta$ Leverage } \\
\hline & \multicolumn{2}{|c|}{ Model 1} & \multicolumn{2}{|c|}{ Model 2} \\
\hline & Coefficient & Std. Error & Coefficient & Std. Error \\
\hline$D V T_{i, t} \cdot D_{i, t}^{a b o v}$ & 0.295 & $(0.055)^{* * *}$ & 0.322 & $(0.127)^{* * *}$ \\
\hline$D V T_{i, t} \cdot D_{i, t}^{b e l o}$ & 0.255 & $(0.033)^{* * *}$ & 0.247 & $(0.054)^{* * *}$ \\
\hline$D V T_{i, t} \cdot D_{i, t}^{a b o v} \cdot R_{i, t-1}^{f i r m}$ & & & 0.036 & $(0.059)$ \\
\hline$D V T_{i, t} \cdot D_{i, t}^{\text {belo }} \cdot R_{i, t-1}^{f i r m}$ & & & -0.252 & $(0.140)^{* *}$ \\
\hline$D V T_{i, t} \cdot D_{i, t}^{a b o v} \cdot R_{t-1}^{\text {macro }}$ & & & -0.059 & $(0.029)^{* *}$ \\
\hline$D V T_{i, t} \cdot D_{i, t}^{\text {belo }} \cdot R_{t-1}^{\text {macro }}$ & & & 0.041 & $(0.170)^{* * *}$ \\
\hline \multicolumn{5}{|c|}{ Panel B: Diagnostic tests } \\
\hline Firm-years & 10,943 & & 9,782 & \\
\hline Firm & 999 & & 963 & \\
\hline $\operatorname{AR}(2)$ & 0.950 & & 1.230 & \\
\hline p-value & 0.341 & & 0.217 & \\
\hline J-statistic & 10.290 & 36 & 23.940 & \\
\hline p-value & 0.740 & & 0.775 & \\
\hline
\end{tabular}
level, respectively. 
Table 4: The Speed of Adjustment (SOA) for Firms Above and Below the Leverage Target at Different Risk Levels

Below are the estimates of the SOA for firms above and below the target leverage ratio at different risk levels. To calculate the SOA we estimate the model below by using the robust two-step systemGMM method (results are given in Table 5) and then we calculate the total derivatives at low $\left(25^{\text {th }}\right.$ percentile), medium ( $50^{t h}$ percentile), and high ( $75^{\text {th }}$ percentile) levels of risk.

$$
\begin{aligned}
L_{i, t}-L_{i, t-1} & =\left(\beta_{1} D_{i, t}^{\text {abov }}+\beta_{2} D_{i, t}^{\text {belo }}\right) D V T_{i, t}+\left(\beta_{3} D_{i, t}^{\text {abov }}+\beta_{4} D_{i, t}^{\text {belo }}\right) D V T_{i, t} \times R_{i, t-1}^{\text {firm }} \\
& +\left(\beta_{5} D_{i, t}^{\text {abov }}+\beta_{6} D_{i, t}^{\text {belo }}\right) D V T_{i, t} \times R_{t-1}^{\text {macro }}+v_{i}+\varepsilon_{i, t}
\end{aligned}
$$

where $L_{i, t}$ is a measure of leverage for firm $i$ in year $t . D V T_{i, t}$ is the deviation of observed (actual) leverage from the target leverage ratio for firm $i$ at time $t, D_{i, t}^{a b o v}$ is a dummy variable equal to one if the leverage ratio is above the target and zero otherwise for firm $i$ at time $t, D_{i, t}^{\text {belo }}$ is a dummy variable equal to one if the leverage ratio is below the target and zero otherwise for firm $i$ at time $t, R_{i, t}^{\text {firm }}$ is a measure of time-varying firm-specific risk and $R_{t}^{\text {macro }}$ is a measure of time-varying macroeconomic risk. Firm-specific risk is drawn from the sales of firms. Macroeconomic risk is proxied by the conditional variance of UK real GDP over the period under investigation. The half-life, the time required for a deviation from the target leverage ratio to be halved, is computed as $\ln (0.5) / \ln (1-\phi)$, where $\phi$ is the estimate of the speed of adjustment toward target leverage. The sample consists of all UK manufacturing firms listed on the London Stock Exchange at any point over the period 1981-2009. The data are drawn from the WorldScope Global database via

\begin{tabular}{|c|c|c|c|c|c|c|c|}
\hline \multicolumn{2}{|c|}{ Risk } & \multicolumn{3}{|c|}{ Firms Above Target } & \multicolumn{3}{|c|}{ Firms Below Target } \\
\hline Firm & Macro & SOA & Estimated & Talf-Life & SOA & Estimated & Ialf-Life \\
\hline$\left(R_{i, t}^{f i r m}\right)$ & $\left(R_{t}^{\text {macro }}\right)$ & $(\%)$ & Std.Error & Years & $(\%)$ & Std.Error & Years \\
\hline High & High & 22.1 & $(0.901)^{* * *}$ & 2.78 & 23.5 & $(0.034)^{* * *}$ & 2.59 \\
\hline High & Medium & 25.3 & $(0.098)^{* * *}$ & 2.38 & 21.3 & $(0.032)^{* * *}$ & 2.89 \\
\hline High & Low & 26.7 & $(0.103)^{* * *}$ & 2.23 & 20.5 & $(0.145)^{* *}$ & 3.02 \\
\hline Medium & High & 21.5 & $(0.091)^{* *}$ & 2.86 & 27.2 & $(0.301)^{* * *}$ & 2.18 \\
\hline Medium & Medium & 24.7 & $(0.099)^{* * *}$ & 2.44 & 25.0 & $(0.029)^{* *}$ & 2.41 \\
\hline Medium & Low & 26.2 & $(0.103)^{* * *}$ & 2.28 & 24.0 & $(0.300)^{* * *}$ & 2.53 \\
\hline Low & High & 21.2 & $(0.091)^{* *}$ & 2.91 & 29.5 & $(0.035)^{* * *}$ & 1.98 \\
\hline Low & Medium & 24.5 & $(0.099)^{* *}$ & 2.47 & 27.3 & $(0.034)^{* * *}$ & 2.17 \\
\hline Low & Low & 25.9 & $(0.103)^{* * *}$ & 2.31 & 26.0 & $(0.103)^{* *}$ & 2.30 \\
\hline Zero & Zero & 32.2 & $(0.128)^{* *}$ & 1.78 & 24.7 & $(0.054)^{* * *}$ & 2.44 \\
\hline
\end{tabular}
DataStream. ${ }^{* * *}$ and ${ }^{* *}$ denote statistical significance at the $1 \%$ and $5 \%$ level, respectively. 


\section{Table 5: Effects of Risk on the Speed of Adjustment while Controlling for Devi-} ations from the Leverage Target and Financial Imbalances

Below are the robust two-step System GMM results of the impact of risk on the marginal effects of deviations from the target leverage ratio and financial imbalances on the speed of adjustment (SOA) for the following model:

$$
\begin{aligned}
L_{i, t}-L_{i, t-1} & =\left(\beta_{1} D_{i, t}^{\text {sur }} D_{i, t}^{\text {abov }}+\beta_{2} D_{i, t}^{\text {def }} D_{i, t}^{\text {abov }}+\beta_{3} D_{i, t}^{\text {sur }} D_{i, t}^{\text {belo }}+\beta_{4} D_{i, t}^{\text {def }} D_{i, t}^{\text {belo }}\right) D V T_{i, t} \\
& +\left(\beta_{5} D_{i, t}^{\text {sur }} D_{i, t}^{\text {abov }}+\beta_{6} D_{i, t}^{\text {def }} D_{i, t}^{\text {abov }}+\beta_{7} D_{i, t}^{\text {sur }} D_{i, t}^{\text {belo }}+\beta_{8} D_{i, t}^{\text {def }} D_{i, t}^{\text {belo }}\right) D V T_{i, t} \times R_{i, t}^{\text {firm }} \\
& +\left(\beta_{9} D_{i, t}^{\text {sur }} D_{i, t}^{\text {abov }}+\beta_{10} D_{i, t}^{\text {def }} D_{i, t}^{\text {abov }}+\beta_{11} D_{i, t}^{\text {sur }} D_{i, t}^{\text {belo }}+\beta_{12} D_{i, t}^{\text {def }} D_{i, t}^{\text {belo }}\right) D V T_{i, t} \times R_{i, t}^{\text {macro }} \\
& +\left(\beta_{13} D_{i, t}^{\text {sur }}+\beta_{14} D_{i, t}^{\text {def }}\right)+v_{i}+\varepsilon_{i, t}
\end{aligned}
$$

where $L_{i, t}$ is a measure of leverage for firm $i$ in year $t . D V T_{i, t}$ is the deviation of observed (actual) leverage from the target leverage ratio for firm $i$ at time $t, D_{i, t}^{a b o v}$ is a dummy variable equal to one if the leverage ratio is above the target and zero otherwise for firm $i$ at time $t, D_{i, t}^{\text {belo }}$ is a dummy variable equal to one if the leverage ratio is below the target and zero otherwise for firm $i$ at time $t . D_{i, t}^{\text {sur }}$ is a dummy variable equal to one if the $i t h$ firm has a financial surplus at time $t$ and zero otherwise, and $D_{i, t}^{\text {def }}$ is a dummy variable equal to one if the $i t h$ firm has a financial deficit at time $t$ and zero otherwise. $U_{i, t}$ is a vector of one-period lagged time-varying firm-specific $\left(R_{i, t}^{f i r m}\right)$ and macroeconomic risk $\left(R_{t}^{\text {macro }}\right)$. Financial deficit is the ratio of the change in working capital plus investment expenditure plus dividends less net cash flows to the book value of total assets. Firm-specific risk is drawn from the sales of firms. Macroeconomic risk is proxied by the conditional variance of UK real GDP over the period under investigation. The sample consists of all UK manufacturing firms listed on the London Stock Exchange at any point over the period 1981-2009. The data are drawn from the WorldScope Global database via DataStream. Panel

\begin{tabular}{|c|c|c|c|c|}
\hline \multicolumn{5}{|c|}{ Panel A: Estimation Results: Dependent Variable: $\Delta$ Leverage } \\
\hline & \multicolumn{2}{|c|}{ Model 1} & \multicolumn{2}{|c|}{ Model 2} \\
\hline & Coefficient & Std. Error & Coefficient & Std. Error \\
\hline$D_{i, t}^{s u r}$ & 0.215 & $(0.081)^{* * *}$ & 0.194 & $(0.078)^{* * *}$ \\
\hline$D_{i, t}^{d e f}$ & 0.094 & $(0.027)^{* * *}$ & 0.069 & $(0.028)^{* * *}$ \\
\hline$D_{i, t}^{s u r} . D V T_{i, t} \cdot D_{i, t}^{a b o v}$ & 0.588 & $(0.197)^{* * *}$ & 0.312 & $(0.126)^{* * *}$ \\
\hline$D_{i, t}^{d e f} . D V T_{i, t} \cdot D_{i, t}^{a b o v}$ & 0.357 & $(0.069)^{* * *}$ & 0.588 & $(0.129)^{* * *}$ \\
\hline$D_{i, t}^{s u r} . D V T_{i, t} \cdot D_{i, t}^{\text {belo }}$ & -0.437 & $(0.216)^{* *}$ & -0.667 & $(0.301)^{* *}$ \\
\hline$D_{i, t}^{d e f} . D V T_{i, t} \cdot D_{i, t}^{b e l o}$ & 0.148 & $(0.033)^{* * *}$ & 0.284 & $(0.109)^{* * *}$ \\
\hline$D_{i, t}^{s u r} \cdot D V T_{i, t} \cdot D_{i, t}^{a b o v} \cdot R_{i, t-1}^{f i r m}$ & & & -0.082 & $(0.039)^{* *}$ \\
\hline$D_{i, t}^{d e f} \cdot D V T_{i, t} \cdot D_{i, t}^{a b o v} \cdot R_{i, t-1}^{f i r m}$ & & & 0.256 & $(0.128)^{* *}$ \\
\hline$D_{i, t}^{s u r} \cdot D V T_{i, t} \cdot D_{i, t}^{\text {belo }} \cdot R_{i, t-1}^{f i r m}$ & & & 0.207 & $(0.118)^{*}$ \\
\hline$D_{i, t}^{d e f} \cdot D V T_{i, t} \cdot D_{i, t}^{\text {belo }} \cdot R_{i, t-1}^{f i r m}$ & & & -0.102 & $(0.134)$ \\
\hline$D_{i, t}^{s u r} \cdot D V T_{i, t} \cdot D_{i, t}^{a b o v} \cdot R_{t-1}^{\text {macro }}$ & & & 0.169 & $(0.065)^{* * *}$ \\
\hline$D_{i, t}^{d e f} \cdot D V T_{i, t} \cdot D_{i, t}^{a b o v} \cdot R_{t-1}^{\text {macro }}$ & & & -0.269 & $(0.058)^{* * *}$ \\
\hline$D_{i, t}^{s u r} \cdot D V T_{i, t} \cdot D_{i, t}^{\text {belo }} \cdot R_{t-1}^{\text {macro }}$ & & & 0.095 & $(0.046)^{* *}$ \\
\hline$D_{i, t}^{\text {def }} \cdot D V T_{i, t} \cdot D_{i, t}^{\text {belo }} \cdot R_{t-1}^{\text {macro }}$ & & & -0.037 & $(0.018)^{* *}$ \\
\hline \multicolumn{5}{|c|}{ Panel B: Diagnostic tests } \\
\hline Firm-years & 9,751 & & 9,571 & \\
\hline Firms & 970 & & 970 & \\
\hline $\operatorname{AR}(2)$ & -0.600 & & -0.310 & \\
\hline p-value & 0.552 & & 0.760 & \\
\hline J-statistic & 45.980 & 38 & 47.980 & \\
\hline p-value & 0.205 & & 0.252 & \\
\hline
\end{tabular}
$\mathrm{B}$ of the table reports the number of firms, the firm-year observations, the $J$ statistics, which is a test of the over identifying restrictions, the Arellano-Bond test, $\operatorname{AR}(2)$, for second-order autocorrelation in the first-differenced residuals and firm-year observations. ${ }^{* *}, * *$, and $*$ denote statistical significance at the $1 \%, 5 \%$, and $10 \%$ level, respectively. 
Table 6: The Speed of Adjustment for Firms having Above/Below-Target Leverage with a Financial Surplus/Deficit at Different Risk Levels

Below are the estimates of the speed of adjustment (SOA) for firms having above- or below-target leverage ratio with a financial deficit or surplus. To calculate the SOA we estimate the model below by using the robust two-step System GMM method (results are given in Table 6) and we then calculate the total derivatives at low ( $25^{\text {th }}$ percentile), medium (50 ${ }^{\text {th }}$ percentile), and high $\left(75^{\text {th }}\right.$ percentile) risk levels.

$$
\begin{aligned}
L_{i, t}-L_{i, t-1} & =\left(\beta_{1} D_{i, t}^{\text {sur }} D_{i, t}^{\text {abov }}+\beta_{2} D_{i, t}^{\text {def }} D_{i, t}^{\text {abov }}+\beta_{3} D_{i, t}^{\text {sur }} D_{i, t}^{\text {belo }}+\beta_{4} D_{i, t}^{\text {def }} D_{i, t}^{\text {belo }}\right) D V T_{i, t} \\
& +\left(\beta_{5} D_{i, t}^{\text {sur }} D_{i, t}^{\text {abov }}+\beta_{6} D_{i, t}^{\text {def }} D_{i, t}^{\text {abov }}+\beta_{7} D_{i, t}^{\text {sur }} D_{i, t}^{\text {belo }}+\beta_{8} D_{i, t}^{\text {def }} D_{i, t}^{\text {belo }}\right) D V T_{i, t} \times R_{i, t}^{\text {firm }} \\
& +\left(\beta_{9} D_{i, t}^{\text {sur }} D_{i, t}^{\text {abov }}+\beta_{10} D_{i, t}^{\text {def }} D_{i, t}^{\text {abov }}+\beta_{11} D_{i, t}^{\text {sur }} D_{i, t}^{\text {belo }}+\beta_{12} D_{i, t}^{\text {def }} D_{i, t}^{\text {belo }}\right) D V T_{i, t} \times R_{i, t}^{\text {macro }} \\
& +\left(\beta_{13} D_{i, t}^{\text {sur }}+\beta_{14} D_{i, t}^{\text {def }}\right)+v_{i}+\varepsilon_{i, t}
\end{aligned}
$$

where $L_{i, t}$ is a measure of leverage for firm $i$ in year $t . D V T_{i, t}$ is the deviation of observed (actual) leverage from the target leverage ratio for firm $i$ at time $t, D_{i, t}^{a b o v}$ is a dummy variable equal to one if the leverage ratio is above the target and zero otherwise for firm $i$ at time $t, D_{i, t}^{b e l o}$ is a dummy variable equal to one if the leverage ratio is below the target and zero otherwise for firm $i$ at time $t . D_{i, t}^{\text {sur }}$ is a dummy variable equal to one if the $i t h$ firm has a financial surplus at time $t$ and zero otherwise, and $D_{i, t}^{\text {def }}$ is a dummy variable equal to one if the $i t h$ firm has a financial deficit at time $t$ and zero otherwise. Financial deficit is the ratio of the change in working capital plus investment expenditure plus dividends less net cash flows to the book value of total assets. $U_{i, t}$ is a vector of one-period lagged time-varying firm-specific $\left(R_{i, t}^{\text {firm }}\right)$ and macroeconomic risk $\left(R_{t}^{\text {macro }}\right)$. Firm-specific risk is drawn from sales of firms. Macroeconomic risk is proxied by the conditional variance of UK real GDP over the period under investigation. The half-life, the time required for a deviation from the target leverage ratio to be halved, is computed as $\ln (0.5) / \ln (1-\phi)$, where $\phi$ is the estimate of the speed of adjustment toward target leverage. The sample consists

\begin{tabular}{|c|c|c|c|c|c|c|c|c|}
\hline & \multicolumn{2}{|c|}{ Risk } & \multicolumn{3}{|c|}{ Firms Above Target } & \multicolumn{3}{|c|}{ Firms Below Target } \\
\hline & $\begin{array}{l}\text { Firm } \\
\left(R_{i, t}^{\text {firm }}\right)\end{array}$ & $\begin{array}{l}\text { Macro } \\
\left(R_{t}^{\text {macro }}\right)\end{array}$ & $\begin{array}{l}\text { SOA } \\
(\%)\end{array}$ & $\begin{array}{l}\text { Estimated } \\
\text { Std.Error }\end{array}$ & $\begin{array}{c}\text { Half-Life } \\
\text { Years }\end{array}$ & $\begin{array}{l}\text { SOA } \\
(\%)\end{array}$ & $\begin{array}{l}\text { Estimated } \\
\text { Std.Error }\end{array}$ & $\begin{array}{c}\text { Half-Life } \\
\text { Years }\end{array}$ \\
\hline \multirow{10}{*}{ 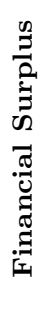 } & High & High & 80.6 & $(0.269) * * *$ & 0.42 & -21.2 & $(0.172)$ & -3.61 \\
\hline & High & Medium & 71.4 & $(0.282)^{* *}$ & 0.55 & -26.4 & $(0.168)$ & -2.96 \\
\hline & High & Low & 67.4 & $(0.289)^{* *}$ & 0.62 & -28.7 & $(0.167)^{*}$ & -2.75 \\
\hline & Medium & High & 81.8 & $(0.270)^{* * *}$ & 0.40 & -24.2 & $(0.192)$ & -3.20 \\
\hline & Medium & Medium & 72.6 & $(0.283)^{* *}$ & 0.54 & -29.4 & $(0.189)$ & -2.69 \\
\hline & Medium & Low & 68.6 & $(0.289)^{* *}$ & 0.60 & -31.7 & $(0.188)^{*}$ & -2.52 \\
\hline & Low & High & 82.5 & $(0.279)^{* * *}$ & 0.39 & -26.1 & $(0.206)$ & -2.99 \\
\hline & Low & Medium & 77.6 & $(0.284)^{* * *}$ & 0.46 & -35.1 & $(0.219)$ & -2.30 \\
\hline & Low & Low & 69.3 & $(0.290)^{* *}$ & 0.59 & -33.5 & $(0.202)^{*}$ & -2.40 \\
\hline & Zero & Zero & 50.6 & $(0.331)^{* *}$ & 0.98 & -47.3 & $(0.227)^{* *}$ & -1.79 \\
\hline \multirow{10}{*}{ 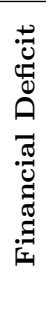 } & High & High & 22.4 & $(0.132)$ & 2.73 & 24.4 & $(0.041)^{* * *}$ & 2.48 \\
\hline & High & Medium & 37.1 & $(0.119) * * *$ & 1.50 & 26.4 & $(0.045)^{* * *}$ & 2.26 \\
\hline & High & Low & 43.5 & $(0.116)^{* * *}$ & 1.21 & 27.3 & $(0.061)^{* * *}$ & 2.17 \\
\hline & Medium & High & 18.7 & $(0.145)$ & 3.35 & 25.8 & $(0.056)^{* * *}$ & 2.32 \\
\hline & Medium & Medium & 33.3 & $(0.132)^{* *}$ & 1.71 & 28.0 & $(0.061)^{* * *}$ & 2.11 \\
\hline & Medium & Low & 39.8 & $(0.145)^{* * *}$ & 1.37 & 28.8 & $(0.062)^{* * *}$ & 2.04 \\
\hline & Low & High & 16.4 & $(0.153)$ & 3.87 & 26.8 & $(0.066)^{* * *}$ & 2.22 \\
\hline & Low & Medium & 31.1 & $(0.140)^{* *}$ & 1.86 & 28.8 & $(0.071)^{* * *}$ & 2.04 \\
\hline & Low & Low & 37.5 & $(0.136)^{* * *}$ & 1.47 & 29.7 & $(0.072)^{* * *}$ & 1.97 \\
\hline & Zero & Zero & 65.7 & $(0.146)^{* * *}$ & 0.65 & 35.3 & $(0.099)^{* * *}$ & 1.59 \\
\hline
\end{tabular}
of all UK manufacturing firms listed on the London Stock Exchange at any point over the period 1981-2009. The data are drawn from the WorldScope Global database via DataStream. ${ }^{* * *}, * *$, and ${ }^{*}$ denote statistical significance at the $1 \%, 5 \%$, and $10 \%$ level, respectively. 


\section{Table 7: Robustness: The Impacts of Risks on Adjustment Speeds with Target} Leverage Estimated without Risk Factors

Below are the estimates of the speed of adjustment (SOA) for firms having above- or below-target leverage ratio with a financial deficit or surplus. To calculate the SOA we estimate the model below by using the robust two-step System GMM method (results are given in Table 6) and we then calculate the total derivatives at low ( $25^{\text {th }}$ percentile), medium (50 ${ }^{\text {th }}$ percentile), and high $\left(75^{t h}\right.$ percentile) risk levels.

$$
\begin{aligned}
L_{i, t}-L_{i, t-1} & =\left(\beta_{1} D_{i, t}^{\text {sur }} D_{i, t}^{\text {abov }}+\beta_{2} D_{i, t}^{\text {def }} D_{i, t}^{\text {abov }}+\beta_{3} D_{i, t}^{\text {sur }} D_{i, t}^{\text {belo }}+\beta_{4} D_{i, t}^{\text {def }} D_{i, t}^{\text {belo }}\right) D V T_{i, t} \\
& +\left(\beta_{5} D_{i, t}^{\text {sur }} D_{i, t}^{\text {abov }}+\beta_{6} D_{i, t}^{\text {def }} D_{i, t}^{\text {abov }}+\beta_{7} D_{i, t}^{\text {sur }} D_{i, t}^{\text {belo }}+\beta_{8} D_{i, t}^{\text {def }} D_{i, t}^{\text {belo }}\right) D V T_{i, t} \times R_{i, t}^{\text {firm }} \\
& +\left(\beta_{9} D_{i, t}^{\text {sur }} D_{i, t}^{\text {abov }}+\beta_{10} D_{i, t}^{\text {def }} D_{i, t}^{\text {abov }}+\beta_{11} D_{i, t}^{\text {sur }} D_{i, t}^{\text {belo }}+\beta_{12} D_{i, t}^{\text {def }} D_{i, t}^{\text {belo }}\right) D V T_{i, t} \times R_{i, t}^{\text {macro }} \\
& +\left(\beta_{13} D_{i, t}^{\text {sur }}+\beta_{14} D_{i, t}^{\text {def }}\right)+v_{i}+\varepsilon_{i, t}
\end{aligned}
$$

where $L_{i, t}$ is a measure of leverage for firm $i$ in year $t . D V T_{i, t}$ is the deviation of observed (actual) leverage from the target leverage ratio for firm $i$ at time $t, D_{i, t}^{a b o v}$ is a dummy variable equal to one if the leverage ratio is above the target and zero otherwise for firm $i$ at time $t, D_{i, t}^{b e l o}$ is a dummy variable equal to one if the leverage ratio is below the target and zero otherwise for firm $i$ at time t. $D_{i, t}^{s u r}$ is a dummy variable equal to one if the $i t h$ firm has a financial surplus at time $t$ and zero otherwise, and $D_{i, t}^{\text {def }}$ is a dummy variable equal to one if the $i t h$ firm has a financial deficit at time $t$ and zero otherwise. Financial deficit is the ratio of the change in working capital plus investment expenditure plus dividends less net cash flows to the book value of total assets. $U_{i, t}$ is a vector of one-period lagged time-varying firm-specific $\left(R_{i, t}^{\text {firm }}\right)$ and macroeconomic risk $\left(R_{t}^{\text {macro }}\right)$. Firm-specific risk is drawn from sales of firms. Macroeconomic risk is proxied by the conditional variance of UK real GDP over the period under investigation. The half-life, the time required for a deviation from the target leverage ratio to be halved, is computed as $\ln (0.5) / \ln (1-\phi)$, where $\phi$ is the estimate of the speed of adjustment toward target leverage. The sample consists

\begin{tabular}{|c|c|c|c|c|c|c|c|c|}
\hline & \multicolumn{2}{|c|}{ Risk } & \multicolumn{3}{|c|}{ Firms Above Target } & \multicolumn{3}{|c|}{ Firms Below Target } \\
\hline & $\begin{array}{l}\text { Firm } \\
\left(R_{i, t}^{\text {firm }}\right)\end{array}$ & $\begin{array}{l}\text { Macro } \\
\left(R_{t}^{\text {macro }}\right)\end{array}$ & $\begin{array}{l}\text { SOA } \\
(\%)\end{array}$ & $\begin{array}{l}\text { Estimated } \\
\text { Std.Error }\end{array}$ & $\begin{array}{c}\text { Half-Life } \\
\text { Years }\end{array}$ & $\begin{array}{l}\text { SOA } \\
(\%)\end{array}$ & $\begin{array}{l}\text { Estimated } \\
\text { Std.Error }\end{array}$ & $\begin{array}{c}\text { Half-Life } \\
\text { Years }\end{array}$ \\
\hline \multirow{10}{*}{ 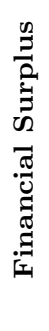 } & High & High & 79.2 & $(0.234)^{* * *}$ & 0.44 & -09.8 & $(0.165)$ & -7.39 \\
\hline & High & Medium & 70.6 & $(0.257)^{* * *}$ & 0.57 & -13.5 & $(0.173)$ & -5.46 \\
\hline & High & Low & 66.9 & $(0.216)^{* * *}$ & 0.63 & -15.2 & $(0.157)$ & -4.91 \\
\hline & Medium & High & 80.3 & $(0.234)^{* * *}$ & 0.43 & -15.1 & $(0.209)$ & -4.91 \\
\hline & Medium & Medium & 71.7 & $(0.218)^{* * *}$ & 0.55 & -18.9 & $(0.187)$ & -4.01 \\
\hline & Medium & Low & 68.0 & $(0.227)^{* * *}$ & 0.61 & -20.5 & $(0.195)$ & -3.72 \\
\hline & Low & High & 81.0 & $(0.228)^{* * *}$ & 0.42 & -18.4 & $(0.232)$ & -4.11 \\
\hline & Low & Medium & 72.4 & $(0.273)^{* * *}$ & 0.54 & -22.1 & $(0.265)$ & -3.47 \\
\hline & Low & Low & 68.7 & $(0.241)^{* * *}$ & 0.60 & -23.7 & $(0.291)$ & -3.26 \\
\hline & Zero & Zero & 51.2 & $(0.189)^{* * *}$ & 0.97 & -36.2 & $(0.176)^{* *}$ & -2.24 \\
\hline \multirow{10}{*}{ 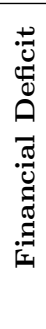 } & High & High & 17.6 & $(0.135)$ & 3.59 & 24.4 & $(0.032)^{* * *}$ & 2.48 \\
\hline & High & Medium & 29.2 & $(0.103)^{* * *}$ & 2.01 & 26.4 & $(0.047)^{* * *}$ & 2.26 \\
\hline & High & Low & 34.3 & $(0.112)^{* * *}$ & 1.65 & 27.2 & $(0.059)^{* * *}$ & 2.18 \\
\hline & Medium & High & 12.8 & $(0.142)$ & 5.08 & 26.0 & $(0.063)^{* * *}$ & 2.30 \\
\hline & Medium & Medium & 24.4 & $(0.076)^{* * *}$ & 2.48 & 28.0 & $(0.052)^{* * *}$ & 2.11 \\
\hline & Medium & Low & 29.5 & $(0.084)^{* * *}$ & 1.98 & 28.9 & $(0.057)^{* * *}$ & 2.03 \\
\hline & Low & High & 09.8 & $(0.143)$ & 6.68 & 27.1 & $(0.072)^{* * *}$ & 2.20 \\
\hline & Low & Medium & 21.5 & $(0.076)^{* * *}$ & 2.86 & 29.0 & $(0.069)^{* * *}$ & 2.02 \\
\hline & Low & Low & 26.6 & $(0.093)^{* * *}$ & 2.24 & 29.9 & $(0.062)^{* * *}$ & 1.95 \\
\hline & Zero & Zero & 47.5 & $(0.117)^{* * *}$ & 1.08 & 35.5 & $(0.087)^{* * *}$ & 1.58 \\
\hline
\end{tabular}
of all UK manufacturing firms listed on the London Stock Exchange at any point over the period 1981-2009. The data are drawn from the WorldScope Global database via DataStream. *** and ** denote statistical significance at the $1 \%$ and $5 \%$ level, respectively. 


\section{Table 8: Robustness: An Alternative Measure of Leverage and the Impacts of Risks on Adjustment Speeds}

Below are the estimates of the speed of adjustment (SOA) for firms having above- or below-target leverage ratio with a financial deficit or surplus. To calculate the SOA we estimate the model below by using the robust two-step System GMM method (results are given in Table 6) and we then calculate the total derivatives at low ( $25^{\text {th }}$ percentile), medium (50 ${ }^{\text {th }}$ percentile), and high $\left(75^{\text {th }}\right.$ percentile) risk levels.

$$
\begin{aligned}
L_{i, t}-L_{i, t-1} & =\left(\beta_{1} D_{i, t}^{\text {sur }} D_{i, t}^{\text {abov }}+\beta_{2} D_{i, t}^{\text {def }} D_{i, t}^{\text {abov }}+\beta_{3} D_{i, t}^{\text {sur }} D_{i, t}^{\text {belo }}+\beta_{4} D_{i, t}^{\text {def }} D_{i, t}^{\text {belo }}\right) D V T_{i, t} \\
& +\left(\beta_{5} D_{i, t}^{\text {sur }} D_{i, t}^{\text {abov }}+\beta_{6} D_{i, t}^{\text {def }} D_{i, t}^{\text {abov }}+\beta_{7} D_{i, t}^{\text {sur }} D_{i, t}^{\text {belo }}+\beta_{8} D_{i, t}^{\text {def }} D_{i, t}^{\text {belo }}\right) D V T_{i, t} \times R_{i, t}^{\text {firm }} \\
& +\left(\beta_{9} D_{i, t}^{\text {sur }} D_{i, t}^{\text {abov }}+\beta_{10} D_{i, t}^{\text {def }} D_{i, t}^{\text {abov }}+\beta_{11} D_{i, t}^{\text {sur }} D_{i, t}^{\text {belo }}+\beta_{12} D_{i, t}^{\text {def }} D_{i, t}^{\text {belo }}\right) D V T_{i, t} \times R_{i, t}^{\text {macro }} \\
& +\left(\beta_{13} D_{i, t}^{\text {sur }}+\beta_{14} D_{i, t}^{\text {def }}\right)+v_{i}+\varepsilon_{i, t}
\end{aligned}
$$

where $L_{i, t}$ is a measure of leverage for firm $i$ in year $t . D V T_{i, t}$ is the deviation of observed (actual) leverage from the target leverage ratio for firm $i$ at time $t, D_{i, t}^{a b o v}$ is a dummy variable equal to one if the leverage ratio is above the target and zero otherwise for firm $i$ at time $t, D_{i, t}^{b e l o}$ is a dummy variable equal to one if the leverage ratio is below the target and zero otherwise for firm $i$ at time $t . D_{i, t}^{\text {sur }}$ is a dummy variable equal to one if the $i t h$ firm has a financial surplus at time $t$ and zero otherwise, and $D_{i, t}^{\text {def }}$ is a dummy variable equal to one if the $i t h$ firm has a financial deficit at time $t$ and zero otherwise. Financial deficit is the ratio of the change in working capital plus investment expenditure plus dividends less net cash flows to the book value of total assets. $U_{i, t}$ is a vector of one-period lagged time-varying firm-specific $\left(R_{i, t}^{\text {firm }}\right)$ and macroeconomic risk $\left(R_{t}^{\text {macro }}\right)$. Firm-specific risk is drawn from sales of firms. Macroeconomic risk is proxied by the conditional variance of UK real GDP over the period under investigation. The half-life, the time required for a deviation from the target leverage ratio to be halved, is computed as $\ln (0.5) / \ln (1-\phi)$, where $\phi$ is the estimate of the speed of adjustment toward target leverage. The sample consists

\begin{tabular}{|c|c|c|c|c|c|c|c|c|}
\hline & & & & cms Above & arget & & irms Below & arget \\
\hline & $\begin{array}{l}\text { Firm } \\
\left(R_{i, t}^{\text {firm }}\right)\end{array}$ & $\begin{array}{l}\text { Macro } \\
\left(R_{t}^{\text {macro }}\right)\end{array}$ & $\begin{array}{l}\text { SOA } \\
(\%)\end{array}$ & $\begin{array}{l}\text { Estimated } \\
\text { Std.Error }\end{array}$ & $\begin{array}{c}\text { Half-Life } \\
\text { Years }\end{array}$ & $\begin{array}{l}\text { SOA } \\
(\%)\end{array}$ & $\begin{array}{l}\text { Estimated } \\
\text { Std.Error }\end{array}$ & $\begin{array}{c}\text { Half-Life } \\
\text { Years }\end{array}$ \\
\hline 0 & High & High & 77.4 & $(0.227)^{* * *}$ & 0.47 & -10.8 & $(0.175)$ & -6.77 \\
\hline 3 & High & Medium & 68.0 & $(0.218)^{* * *}$ & 0.61 & -13.6 & $(0.168)$ & -5.43 \\
\hline 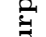 & High & Low & 63.9 & $(0.203)^{* * *}$ & 0.68 & -14.9 & $(0.182)$ & -5.00 \\
\hline$\tilde{n}$ & Medium & High & 79.4 & $(0.254)^{* * *}$ & 0.44 & -16.0 & $(0.197)$ & -4.67 \\
\hline శ & Medium & Medium & 70.0 & $(0.220)^{* * *}$ & 0.57 & -18.9 & $(0.182)$ & -4.01 \\
\hline$\ddot{0}$ & Medium & Low & 65.9 & $(0.226)^{* * *}$ & 0.64 & -20.1 & $(0.189)$ & -3.78 \\
\hline జี & Low & High & 80.7 & $(0.265)^{* * *}$ & 0.42 & -19.2 & $(0.234)$ & -3.95 \\
\hline $\mathfrak{z}$ & Low & Medium & 71.3 & $(0.205)^{* * *}$ & 0.56 & -22.0 & $(0.217)$ & -3.48 \\
\hline & Low & Low & 67.1 & $(0.211)^{* * *}$ & 0.62 & -23.3 & $(0.287)$ & -3.31 \\
\hline & Zero & Zero & 48.7 & $(0.143)^{* * *}$ & 1.04 & -33.8 & $(0.138)^{* *}$ & -2.38 \\
\hline & High & High & 18.2 & $(0.137)$ & 3.45 & 27.3 & $(0.034)^{* * *}$ & 2.18 \\
\hline 荧 & High & Medium & 29.0 & $(0.098)^{* * *}$ & 2.02 & 28.8 & $(0.054)^{* * *}$ & 2.04 \\
\hline $\mathbb{E}$ & High & Low & 33.8 & $(0.113)^{* * *}$ & 1.68 & 29.4 & $(0.078) * * *$ & 1.99 \\
\hline A & Medium & High & 13.0 & $(0.156)$ & 4.96 & 29.0 & $(0.043)^{* * *}$ & 2.02 \\
\hline ప్ & Medium & Medium & 23.9 & $(0.072)^{* * *}$ & 2.54 & 30.5 & $(0.058) * * *$ & 1.91 \\
\hline$\ddot{g}$ & Medium & Low & 28.6 & $(0.086)^{* * *}$ & 2.06 & 31.1 & $(0.059)^{* * *}$ & 1.86 \\
\hline สี & Low & High & 09.9 & $(0.176)$ & 6.65 & 30.1 & $(0.079)^{* * *}$ & 1.94 \\
\hline$\underset{I}{I}$ & Low & Medium & 20.7 & $(0.087)^{* *}$ & 2.99 & 31.5 & $(0.053)^{* * *}$ & 1.83 \\
\hline & Low & Low & 25.5 & $(0.067)^{* * *}$ & 2.36 & 32.2 & $(0.061)^{* * *}$ & 1.79 \\
\hline & Zero & Zero & 44.3 & $(0.113)^{* * *}$ & 1.18 & 36.8 & $(0.067)^{* * *}$ & 1.51 \\
\hline
\end{tabular}
of all UK manufacturing firms listed on the London Stock Exchange at any point over the period 1981-2009. The data are drawn from the WorldScope Global database via DataStream. *** and ** denote statistical significance at the $1 \%$ and $5 \%$ level, respectively. 


\section{Table 9: Robustness: The Impacts of Risks on Adjustment Speeds with Macroe-} conomic Conditions-Adjusted Firm-Specific Risk

Below are the estimates of the speed of adjustment (SOA) for firms having above- or below-target leverage ratio with a financial deficit or surplus. To calculate the SOA we estimate the model below by using the robust two-step System GMM method (results are given in Table 6) and we then calculate the total derivatives at low ( $25^{\text {th }}$ percentile), medium ( $50^{\text {th }}$ percentile), and high $\left(75^{t h}\right.$ percentile) risk levels.

$$
\begin{aligned}
L_{i, t}-L_{i, t-1} & =\left(\beta_{1} D_{i, t}^{\text {sur }} D_{i, t}^{\text {abov }}+\beta_{2} D_{i, t}^{\text {def }} D_{i, t}^{\text {abov }}+\beta_{3} D_{i, t}^{\text {sur }} D_{i, t}^{\text {belo }}+\beta_{4} D_{i, t}^{\text {def }} D_{i, t}^{\text {belo }}\right) D V T_{i, t} \\
& +\left(\beta_{5} D_{i, t}^{\text {sur }} D_{i, t}^{\text {abov }}+\beta_{6} D_{i, t}^{\text {def }} D_{i, t}^{\text {abov }}+\beta_{7} D_{i, t}^{\text {sur }} D_{i, t}^{\text {belo }}+\beta_{8} D_{i, t}^{\text {def }} D_{i, t}^{\text {belo }}\right) D V T_{i, t} \times R_{i, t}^{\text {firm }} \\
& +\left(\beta_{9} D_{i, t}^{\text {sur }} D_{i, t}^{\text {abov }}+\beta_{10} D_{i, t}^{\text {def }} D_{i, t}^{\text {abov }}+\beta_{11} D_{i, t}^{\text {sur }} D_{i, t}^{\text {belo }}+\beta_{12} D_{i, t}^{\text {def }} D_{i, t}^{\text {belo }}\right) D V T_{i, t} \times R_{i, t}^{\text {macro }} \\
& +\left(\beta_{13} D_{i, t}^{\text {sur }}+\beta_{14} D_{i, t}^{\text {def }}\right)+v_{i}+\varepsilon_{i, t}
\end{aligned}
$$

where $L_{i, t}$ is a measure of leverage for firm $i$ in year $t . D V T_{i, t}$ is the deviation of observed (actual) leverage from the target leverage ratio for firm $i$ at time $t, D_{i, t}^{a b o v}$ is a dummy variable equal to one if the leverage ratio is above the target and zero otherwise for firm $i$ at time $t, D_{i, t}^{b e l o}$ is a dummy variable equal to one if the leverage ratio is below the target and zero otherwise for firm $i$ at time t. $D_{i, t}^{s u r}$ is a dummy variable equal to one if the $i t h$ firm has a financial surplus at time $t$ and zero otherwise, and $D_{i, t}^{d e f}$ is a dummy variable equal to one if the $i t h$ firm has a financial deficit at time $t$ and zero otherwise. Financial deficit is the ratio of the change in working capital plus investment expenditure plus dividends less net cash flows to the book value of total assets. $U_{i, t}$ is a vector of one-period lagged time-varying firm-specific $\left(R_{i, t}^{\text {firm }}\right)$ and macroeconomic risk $\left(R_{t}^{\text {macro }}\right)$. Firm-specific risk is drawn from sales of firms after controlling for macroeconomic conditions (log of real GDP and log of CPI are also included in the specification). Macroeconomic risk is proxied by the conditional variance of UK real GDP over the period under investigation. The half-life, the time required for a deviation from the target leverage ratio to be halved, is computed as

\begin{tabular}{|c|c|c|c|c|c|c|c|c|}
\hline & \multicolumn{2}{|c|}{ Risk } & \multicolumn{3}{|c|}{ Firms Above Target } & \multicolumn{3}{|c|}{ Firms Below Target } \\
\hline & $\begin{array}{l}\text { Firm } \\
\left(R_{i, t}^{\text {firm }}\right) \\
\end{array}$ & $\begin{array}{l}\text { Macro } \\
\left(R_{t}^{\text {macro }}\right)\end{array}$ & $\begin{array}{l}\text { SOA } \\
(\%)\end{array}$ & $\begin{array}{l}\text { Estimated } \\
\text { Std.Error }\end{array}$ & $\begin{array}{c}\text { Half-Life } \\
\text { Years }\end{array}$ & $\begin{array}{l}\text { SOA } \\
(\%)\end{array}$ & $\begin{array}{l}\text { Estimated } \\
\text { Std.Error }\end{array}$ & $\begin{array}{c}\text { Half-Life } \\
\text { Years }\end{array}$ \\
\hline \multirow{10}{*}{ 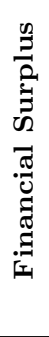 } & High & High & 80.1 & $(0.237)^{* * *}$ & 0.43 & -13.3 & $(0.189)$ & -5.55 \\
\hline & High & Medium & 70.2 & $(0.281)^{* * *}$ & 0.57 & -16.7 & $(0.177)$ & -4.49 \\
\hline & High & Low & 65.8 & $(0.233)^{* * *}$ & 0.65 & -18.2 & $(0.192)$ & -4.15 \\
\hline & Medium & High & 82.2 & $(0.242)^{* * *}$ & 0.40 & -18.6 & $(0.215)$ & -4.07 \\
\hline & Medium & Medium & 72.3 & $(0.213) * * *$ & 0.54 & -22.0 & $(0.287)$ & -3.49 \\
\hline & Medium & Low & 67.9 & $(0.241)^{* * *}$ & 0.61 & -23.5 & $(0.194)$ & -3.29 \\
\hline & Low & High & 83.5 & $(0.252)^{* * *}$ & 0.38 & -21.8 & $(0.253)$ & -3.52 \\
\hline & Low & Medium & 73.5 & $(0.231)^{* * *}$ & 0.52 & -25.2 & $(0.276)$ & -3.09 \\
\hline & Low & Low & 69.2 & $(0.214)^{* * *}$ & 0.59 & -26.7 & $(0.259)$ & -2.93 \\
\hline & Zero & Zero & 49.6 & $(0.145)^{* * *}$ & 1.01 & -38.4 & $(0.165)^{* *}$ & -2.13 \\
\hline \multirow{10}{*}{ 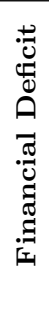 } & High & High & 18.8 & $(0.154)$ & 3.32 & 25.6 & $(0.032)^{* * *}$ & 2.34 \\
\hline & High & Medium & 29.7 & $(0.058)^{* * *}$ & 1.97 & 27.2 & $(0.047)^{* * *}$ & 2.19 \\
\hline & High & Low & 34.4 & $(0.101)^{* * *}$ & 1.64 & 27.8 & $(0.059)^{* * *}$ & 2.13 \\
\hline & Medium & High & 13.8 & $(0.187)$ & 4.66 & 27.5 & $(0.063)^{* * *}$ & 2.16 \\
\hline & Medium & Medium & 24.6 & $(0.065)^{* * *}$ & 2.45 & 29.0 & $(0.052)^{* * *}$ & 2.02 \\
\hline & Medium & Low & 29.4 & $(0.082)^{* * *}$ & 1.99 & 29.7 & $(0.057)^{* * *}$ & 1.97 \\
\hline & Low & High & 10.8 & $(0.165)$ & 6.08 & 28.6 & $(0.072)^{* * *}$ & 2.05 \\
\hline & Low & Medium & 21.6 & $(0.073)^{* * *}$ & 2.85 & 30.2 & $(0.069)^{* * *}$ & 1.93 \\
\hline & Low & Low & 26.3 & $(0.061)^{* * *}$ & 2.27 & 30.8 & $(0.062)^{* * *}$ & 1.88 \\
\hline & Zero & Zero & 45.3 & $(0.098)^{* * *}$ & 1.15 & 35.7 & $(0.098)^{* * *}$ & 1.57 \\
\hline
\end{tabular}
$\ln (0.5) / \ln (1-\phi)$, where $\phi$ is the estimate of the speed of adjustment toward target leverage. The sample consists of all UK manufacturing firms listed on the London Stock Exchange at any point over the period 1981-2009. The data are drawn from the WorldScope Global database via DataStream. ${ }^{* * *}$ and ${ }^{* *}$ denote statistical significance at the $1 \%$ and $5 \%$ level, respectively. 


\section{Table 10: Robustness: Alternative Measures of Risk and the Alternative Estimate} of Firms' Target Leverage

Table 10 reports results from estimating the following model for alternative measures of risk and the alternative measure of the firm target leverage levels:

$$
\begin{aligned}
L_{i, t}-L_{i, t-1} & =\left(\beta_{1} D_{i, t}^{\text {sur }} D_{i, t}^{\text {abov }}+\beta_{2} D_{i, t}^{\text {def }} D_{i, t}^{\text {abov }}+\beta_{3} D_{i, t}^{\text {sur }} D_{i, t}^{\text {belo }}+\beta_{4} D_{i, t}^{\text {def }} D_{i, t}^{\text {belo }}\right) D V T_{i, t} \\
& +\left(\beta_{5} D_{i, t}^{\text {sur }} D_{i, t}^{\text {abov }}+\beta_{6} D_{i, t}^{\text {def }} D_{i, t}^{\text {abov }}+\beta_{7} D_{i, t}^{\text {sur }} D_{i, t}^{\text {belo }}+\beta_{8} D_{i, t}^{\text {def }} D_{i, t}^{\text {belo }}\right) D V T_{i, t} \times R_{i, t}^{\text {firm }} \\
& +\left(\beta_{9} D_{i, t}^{\text {sur }} D_{i, t}^{\text {abov }}+\beta_{10} D_{i, t}^{\text {def }} D_{i, t}^{\text {abov }}+\beta_{11} D_{i, t}^{\text {sur }} D_{i, t}^{\text {belo }}+\beta_{12} D_{i, t}^{\text {def }} D_{i, t}^{\text {belo }}\right) D V T_{i, t} \times R_{i, t}^{\text {macro }} \\
& +\left(\beta_{13} D_{i, t}^{\text {sur }}+\beta_{14} D_{i, t}^{\text {def }}\right)+v_{i}+\varepsilon_{i, t}
\end{aligned}
$$

where $L_{i, t}$ is a measure of leverage for firm $i$ in year $t . D V T_{i, t}$ is the deviation of observed (actual) leverage from the target leverage ratio for firm $i$ at time $t, D_{i, t}^{a b o v}$ is a dummy variable equal to one if the leverage ratio is above the target and zero otherwise for firm $i$ at time $t, D_{i, t}^{b e l o}$ is a dummy variable equal to one if the leverage ratio is below the target and zero otherwise for firm $i$ at time $t . D_{i, t}^{\text {sur }}$ is a dummy variable equal to one if the $i t h$ firm has a financial surplus at time $t$ and zero otherwise, and $D_{i, t}^{d e f}$ is a dummy variable equal to one if the $i t h$ firm has a financial deficit at time $t$ and zero otherwise. $U_{i, t}$ is a vector of one-period lagged time-varying firm-specific $\left(R_{i, t}^{\text {firm }}\right)$ and macroeconomic risk $\left(R_{t}^{\text {macro }}\right)$. Firm-specific risk is drawn from firms' cash flow realizations. Macroeconomic risk is proxied by the conditional variance of Consumer Price Index (CPI) over the period under investigation. Financial deficit is the ratio of the change in working capital plus investment expenditure plus dividends less net cash flows to the book value of total assets. Model 1 estimates the effect of our alternative measures of risk on adjustments, while Model 2 quantifies the effect of risk on adjustments when the firm target leverage is proxied by the historical mean of the firm leverage. The sample consists of all UK manufacturing firms listed on the London Stock Exchange at any point over the period 1981-2009. The data are drawn from the WorldScope database via DataStream. Panel B of the

\begin{tabular}{|c|c|c|c|c|}
\hline & Model 1 & \multicolumn{3}{|c|}{ Panel A: Estimation Results; Dependent Variable: $\Delta$ Leverage } \\
\hline & Coefficient & Std. Error & Coefficient & Std. Error \\
\hline$D_{i, t}^{\text {sur }}$ & 0.197 & $(0.081)^{* * *}$ & 0.164 & $(0.041)^{* * *}$ \\
\hline$D_{i, t}^{d e f}$ & 0.081 & $(0.027)^{* * *}$ & 0.064 & $(0.016)^{* * *}$ \\
\hline$D_{i, t}^{s u r} . D V T_{i, t} \cdot D_{i, t}^{a b o v}$ & 0.433 & $(0.197)^{* * *}$ & 0.372 & $(0.123)^{* * *}$ \\
\hline$D_{i, t}^{d e f} . D V T_{i, t} \cdot D_{i, t}^{a b o v}$ & 0.610 & $(0.069)^{* * *}$ & 0.568 & $(0.075)^{* * *}$ \\
\hline$D_{i, t}^{s u r} . D V T_{i, t} \cdot D_{i, t}^{\text {belo }}$ & -0.866 & $(0.216)^{* *}$ & -0.609 & $(0.167)^{* *}$ \\
\hline$D_{i, t}^{d e f} \cdot D V T_{i, t} \cdot D_{i, t}^{\text {belo }}$ & 0.225 & $(0.033)^{* * *}$ & 0.474 & $(0.054)^{* * *}$ \\
\hline$D_{i, t}^{s u r} \cdot D V T_{i, t} \cdot D_{i, t}^{a b o v} \cdot R_{i, t-1}^{f i r m}$ & -0.210 & $(0.018)^{* * *}$ & -0.087 & $(0.025)^{* *}$ \\
\hline$D_{i, t}^{d e f} \cdot D V T_{i, t} \cdot D_{i, t}^{a b o v} \cdot R_{i, t-1}^{f i r m}$ & 0.019 & $(0.001)^{* * *}$ & 0.215 & $(0.088)^{* * *}$ \\
\hline$D_{i, t}^{\text {sur }} \cdot D V T_{i, t} \cdot D_{i, t}^{\text {belo }} \cdot R_{i, t-1}^{\text {firm }}$ & 0.063 & $(0.003)^{* * *}$ & 0.258 & $(0.031)^{* * *}$ \\
\hline$D_{i, t}^{\text {def }} \cdot D V T_{i, t} \cdot D_{i, t}^{\text {belo }} \cdot R_{i, t-1}^{\text {firm }}$ & -0.001 & $(0.001)$ & -0.111 & $(0.018)^{* * *}$ \\
\hline$D_{i, t}^{s u r} \cdot D V T_{i, t} \cdot D_{i, t}^{a b o v} \cdot R_{t-1}^{\text {macro }}$ & 0.659 & $(0.256)^{* * *}$ & 0.141 & $(0.036)^{* * *}$ \\
\hline$D_{i, t}^{\text {def }} \cdot D V T_{i, t} \cdot D_{i, t}^{a b o v} \cdot R_{t-1}^{\text {macro }}$ & -2.146 & $(0.442)^{* * *}$ & -0.221 & $(0.035)^{* * *}$ \\
\hline$D_{i, t}^{\text {sur }} \cdot D V T_{i, t} \cdot D_{i, t}^{\text {belo }} \cdot R_{t-1}^{\text {macro }}$ & 1.627 & $(0.518)^{* * *}$ & 0.061 & $(0.025)^{* *}$ \\
\hline$D_{i, t}^{\text {def }} \cdot D V T_{i, t} \cdot D_{i, t}^{\text {belo }} \cdot R_{t-1}^{\text {macro }}$ & -0.298 & $(0.097)^{* * *}$ & -0.046 & $(0.013)^{* * *}$ \\
\hline \multicolumn{5}{|c|}{ Panel B: Diagnostic tests } \\
\hline Firm-years & 9,751 & & 9,751 & \\
\hline Firm & 970 & 42 & 970 & \\
\hline $\operatorname{AR}(2)$ & -0.790 & 40 & 0.310 & \\
\hline p-value & 0.428 & & 0.757 & \\
\hline J-statistic & 34.240 & & 74.770 & \\
\hline p-value & 0.159 & & 0.241 & \\
\hline
\end{tabular}
table reports the number of firms, the firm-year observations, the $J$ statistics, which is a test of the over identifying restrictions, the Arellano-Bond test, $\operatorname{AR}(2)$, for second-order autocorrelation in the first-differenced residuals, and firm-year observations. *** and ** denote statistical significance at the $1 \%$ and $5 \%$ level, respectively. 


\section{Appendix A}

\section{Table A: Estimated Capital Structure Adjustment Speeds in Prior Empirical Studies}

\begin{tabular}{|c|c|c|c|c|}
\hline Article & Sample Period & Country & SOA & Half-Life \\
\hline Jalilvand and Harris (1984) & $1966-1978$ & USA & $56.1 \%^{a}, 10.9 \%^{b}$ & $0.8,6.0$ years \\
\hline Ozkan (2001) & 1984-1996 & UK & $56.9 \%$ & 0.8 years \\
\hline Fama and French (2002) & 1965-1999 & USA & $10.0 \%^{c}, 18.0 \%^{d}$ & $6.6,3.5$ years \\
\hline Flannery and Rangan (2006) & $1965-2001$ & USA & $34.0 \%$ & 1.7 years \\
\hline Kayhan and Titman (2007) & $1960-2003$ & USA & $10.0 \%$ & 6.6 years \\
\hline Flannery and Hankins (2007) & $1968-2004$ & USA & $22.0 \%$ & 2.8 years \\
\hline $\mathrm{Xu}(2007)$ & $1970-2004$ & USA & $18.0 \%$ & 3.5 years \\
\hline Lemmon et al. (2008) & $1963-2003$ & USA & $25.0 \%$ & 2.4 years \\
\hline Antoniou et al. (2008) & $1987-2000$ & UK, USA & $32.0 \%^{e}, 32.2 \%^{f}$ & $1.8,1.8$ years \\
\hline Byoun (2008) & $1971-2003$ & USA & $33.0 \%^{g}, 20.0 \%^{h}$ & $1.7,3.1$ years \\
\hline Brav (2009) & $1997-2003$ & UK & $10.2 \%^{j}, 22.5 \%^{k}$ & $6.4,2.7$ years \\
\hline Huang and Ritter (2009) & $1963-2001$ & USA & $17.0 \%$ & 3.7 years \\
\hline Chang and Dasgupta (2009) & $1971-2004$ & USA & $37.8 \%$ & 1.4 years \\
\hline Elsas and Florysiak (2010) & $1965-2009$ & USA & $26.0 \%$ & 2.3 years \\
\hline Cook and Tang (2010) & $1977-2006$ & USA & $46.1 \%^{m}, 43.7 \%^{n}$ & $1.1,1.2$ years \\
\hline Elsas and Florysiak (2011) & $1965-2009$ & USA & $50.5 \%^{0}, 45.0 \%^{p}$ & $1.0,1.1$ years \\
\hline Faulkender et al. (2012) & $1965-2006$ & USA & $22.9 \%^{q}, 69.3 \%^{r}$ & $2.6,0.6$ years \\
\hline
\end{tabular}

${ }^{a}$ For debt financing.

${ }^{b}$ For equity financing.

${ }^{c}$ Firms that pay dividends.

${ }^{d}$ Firms that do not pay dividends.

${ }^{e} \mathrm{UK}$ firms.

${ }^{f}$ US firms.

${ }^{g}$ Firms that are above target leverage and have a financial surplus.

${ }^{h}$ Firms that are above target leverage and have a financial deficit.

${ }^{j}$ Public firms.

${ }^{k}$ Private firms.

${ }^{m}$ When the economy in an expansionary phase.

${ }^{n}$ When the economy in a recessionary phase.

${ }^{0}$ Highly over-levered firms.

${ }^{p}$ Highly under-levered firms.

${ }^{q}$ Under-levered firms with near-zero cash flow realization.

${ }^{r}$ Over-levered firms with excess cash flow realization. 


\title{
Appendix B
}

\section{Table B: Variable Definitions}

\author{
Variables \\ Book leverage \\ Book debt \\ Book equity \\ Market-to-book \\ value \\ Profitability \\ Firm size \\ Non-debt tax shield \\ Tangibility \\ Investment \\ Two-year stock re- \\ turns \\ Financial deficit \\ Target leverage \\ Leverage deviation \\ Firm-specific risk \\ Macroeconomic risk

\section{Definition} \\ The ratio of book debt to the book value of total assets. \\ Total assets less the book value of equity. \\ Total assets minus total liabilities and preferred stock plus deferred \\ taxes and convertible debt. \\ The book value of total assets minus the book value of equity plus \\ the market value of equity divided by the book value of total assets. \\ The ratio of earnings before interest, taxes and depreciation to the \\ book value of total assets. \\ Natural logarithm of net sales. \\ Ratio of total depreciation expense to the book value of total assets. \\ The ratio of net plant, property and equipment to the book value \\ of assets. \\ The ratio of total capital expenditures to the book value of total \\ assets. \\ Difference between share prices at time $t$ and share prices at time \\ $t-2$. \\ The ratio of the change in working capital plus investment plus \\ dividends less net cash flow to the book value of total assets. \\ Estimated from the regression of observed leverage on the firm- \\ specific variables and risk measures. \\ Deviations of current leverage from the target leverage ratio. \\ Drawn from net sales of firms scaled by the book value of total \\ assets. \\ Proxied by the conditional variance of UK real GDP obtained from \\ the ARCH model.
}




\section{Appendix C}

\section{Table C: ARCH Model Estimates for Macroeconomic Risk}

Panel A reports the estimates obtained by estimating the ARCH(1) model for real gross domestic (GDP) over the period 1975Q1-2009Q4. Specifically, allowing an ARMA term in the mean equation we estimate the following mean and variance equations simultaneously:

$$
\begin{aligned}
\Delta G D P_{t} & =\omega+\eta \Delta G D P_{t-1}+\epsilon_{t} \\
\sigma_{t}^{2} & =\alpha+\beta \epsilon_{t-1}^{2}
\end{aligned}
$$

where $\omega$ is a constant term and $\eta$ is the autoregressive parameter. The conditional variance, $\sigma_{t}^{2}$, is the one-periodahead forecast variance based on prior information. $\alpha$ is a constant term and $\epsilon \mid \Delta G D P_{t-1} \sim N\left(0, \sigma_{t-1}^{2}\right)$ is the innovation in real GDP. In the variance equation, the weights are $(1-\alpha, \beta)$ and the long-run average variance is $\sqrt{\alpha /(1-\beta)}$, where $\alpha>0$ and $0<\beta<1$. The figures given in parentheses are standard errors. The estimates of the log-likelihood, Lagrange multiplier $(A R C H \mathrm{LM})$ test and Q-statistics to test for the remaining ARCH effects in the model are given in Panel B. Seasonally adjusted quarterly data spanning 1975Q1-2009Q4 on UK real GDP are taken from the Office for National Statistics (ONS) database (Pn: A2: ABMI: Gross Domestic Product: chained volume measure). Statistical significance at the $1 \%$ and $5 \%$ level is indicated by three and two asterisks, respectively.

\begin{tabular}{lccc}
\hline \multicolumn{4}{c}{ Panel A: ARCH(1) Estimates } \\
\hline \multirow{2}{*}{ Regressors } & \multicolumn{3}{c}{$\Delta$ GDP } \\
\cline { 2 - 4 } & Coefficients & Std.Error \\
\hline$\Delta G D P_{t-1}$ & 0.777 & $(8.450)^{* * *}$ \\
Constant & 0.415 & $(0.159)^{* * *}$ \\
\hline AR(1) & -0.808 & $(0.059)^{* * *}$ \\
MA(1) & 0.346 & $(0.153)^{* *}$ \\
MA(2) & -0.532 & $(0.140)^{* * *}$ \\
ARCH(1) & 0.781 & $(0.234)^{* * *}$ \\
Constant & 0.813 & & \\
\hline & Panel B: Tests for & remaining ARCH effects \\
\hline Log-likelihood & & -233.961 & \\
Observations & & 139.000 & \\
LM-test(4) & & 0.610 & \\
P-value & & 0.962 & \\
LM-test(8) & & 1.050 & \\
P-value & & 0.994 & \\
Q(4) & & 1.128 & \\
P-value & & 0.889 & \\
Q(8) & & 2.527 & \\
P-value & & 0.960 & \\
\hline
\end{tabular}




\section{Appendix D}

\section{Table D: Robust Two-step System GMM Estimates for the Determinants of Leverage}

Below are the robust two-step System GMM estimates for the following model:

$$
L_{i, t}=\beta_{0}+\beta_{1} X_{i, t-1}+\beta_{2} R_{i, t-1}^{\text {firm }}+\beta_{3} R_{i, t-1}^{\text {macro }}+v_{i}+\varepsilon_{i, t}
$$

where $L_{i, t}$ is a measure of the book leverage of firm $i$ in year $t . X_{i, t}$ is a vector of the firm-specific variables. $R_{i, t}^{f i r m}$ is a measure of time-varying firm-specific risk. $R_{t}^{\text {macro }}$ is a measure of time-varying macroeconomic risk. The term $v_{i}$ captures the effects of time-invariant unobservable firm-specific factors. The term $\varepsilon_{i, t}$ represents the time-varying residuals. Subscripts $i$ and $t$ denote firm and time period, respectively. The variables are defined as follows. Book leverage is the ratio of the book value of total debt to the book value of total assets. The market-to-book value ratio is defined as the book value of the total book assets less the book value of equity plus the market value of equity divided by the book value of total assets. Investment is the ratio of total expenditures to purchase fixed tangible assets to the book value of total assets. Profitability is the ratio of earnings before interest, taxes, and depreciation to the total book assets. Tangibility is the ratio of net plant, property, and equipment to the total book assets. The two-year stock return is the percentage change between share prices at time $t$ and share prices at time $t-2$. Firm size is defined as the logarithm of net sales. The non-debt tax shield is defined as total depreciation expense divided by the book value of total assets. Firm-specific risk is drawn from sales of firms. Macroeconomic risk is proxied by the conditional variance of UK real GDP over the period under investigation. The sample consists of all UK manufacturing firms listed on the London Stock Exchange at any point over the period 1981-2009. The data are drawn from the WorldScope Global database via DataStream. Panel B reports the number of firms, the firm-year observations, the $J$ statistics, which is a test of the over identifying restrictions, and the Arellano-Bond test, $\operatorname{AR}(2)$, for second-order autocorrelation in the first-differenced residuals. $* * *$ and $* *$ denote statistical significance at the $1 \%$ and $5 \%$ level, respectively.

\begin{tabular}{|c|c|c|}
\hline \multicolumn{3}{|c|}{ Panel A: Estimation results } \\
\hline Regressors & Coefficient & Std. Error \\
\hline Leverage $_{i, t-1}$ & 0.688 & $(0.093)^{* * *}$ \\
\hline Market-to-Book $i, t-1$ & -0.011 & $(0.005)^{* *}$ \\
\hline Investment $_{i, t-1}$ & 0.402 & $(0.128)^{* * *}$ \\
\hline Profitability $_{i, t-1}$ & 0.251 & $(0.130)^{* *}$ \\
\hline Tangibility $_{i, t-1}$ & -0.429 & $(0.135)^{* * *}$ \\
\hline Firm Size $i, t-1$ & 0.034 & $(0.013)^{* * *}$ \\
\hline Two-year Stock Return ${ }_{i, t-1}$ & -0.120 & $(0.016)^{* * *}$ \\
\hline Non-debt Tax Shields S $_{i, t-1}$ & 0.772 & $(0.388)^{* *}$ \\
\hline$R_{i, t-1}^{f i r m}$ & -0.101 & $(0.032)^{* *}$ \\
\hline$R_{t-1}^{\text {macro }}$ & -0.006 & $(0.002)^{* * *}$ \\
\hline Constant & -0.245 & $(0.124)^{* *}$ \\
\hline & Panel B: 1 & \\
\hline$\overline{\text { Firm-years }}$ & 10,882 & \\
\hline Firms & 994 & \\
\hline $\operatorname{AR}(2)$ & -0.890 & \\
\hline p-value & 0.373 & \\
\hline J-statistic & 57.620 & \\
\hline p-value & 0.379 & \\
\hline
\end{tabular}

